\title{
Análise de uma Disciplina em Práticas de Ensino de Física na Perspectiva da Teoria Histórico-Cultural da Atividade ${ }^{1}$
}

\author{
Analysis of a 'Practices on Physics Teaching' course in the Cultural \\ and Historical Activity Theory Perspective
}

\author{
Glauco S. F. da Silva ${ }^{a}$; Alberto Villani ${ }^{b}$ \\ a Centro Federal de Educação Tecnológica Celso Suckow da Fonseca, Petrópolis, Brasil - glauco.silva@ cefet-rj.br \\ b Instituto de Física, Universidade de São Paulo, São Paulo, Brasil - avillani@if.usp.br
}

\section{Palavras-chave: \\ Ensino de física. Formação docente. Prática de ensino de física. Teoria da atividade.}

\begin{abstract}
Resumo: O objetivo deste artigo é apresentar e discutir, à luz da Teoria da Atividade, o episódio da atividade de confeccionar o roteiro de experimentos levados para escola por estagiários, no contexto de uma disciplina de Práticas em Ensino de Física em que havia 100 horas de carga horária de Estágio Supervisionado, de uma universidade pública estadual. Mostraremos a gênese da atividade enquanto um planejamento da equipe pedagógica, as modificações nas atividades a partir de uma discussão entre a professora e os licenciandos, a mudança e nova proposta que emerge de um processo coletivo entre os licenciandos e a professora. Vamos defender a ideia de que as mudanças ocorridas no decurso da atividade, resultando em uma nova proposta, estão relacionadas com a vivência dos licenciandos na escola durante a realização do Estágio Supervisionado.
\end{abstract}

\section{Keywords:}

Physics education.

Teacher education.

Physics teaching

practice. Cultural

historical activity theory (chat).

\begin{abstract}
Based on the Cultural and Historical Activity Theory, this study aims to present and discuss some events happened during the course called Practices on Physics Teaching. This course is available at a Brazilian public university to thirdyear pre-service physics teachers. In this paper we focused on three months classes in which data were gathered by video recordings. We will show the genesis of the "lab guide activity"; the changes made by the professor and pre-services teachers after discussing the rules of the activity; and the new activity that emerged from the collective process among them. In the end we propose an initial model based on the activity system to improve the relationship between universities and high schools.
\end{abstract}

\footnotetext{
${ }^{1}$ Uma versão preliminar deste trabalho foi apresentada no X ENPEC, 2015.
} 


\section{Introdução}

Os estudos sobre a formação de professores estão presentes ao longo dos anos na agenda de pesquisa em Educação com diferentes questões exploradas e, consequentemente, com diferentes abordagens teórico-metodológicas. As tendências e modelos de formação e trabalho docente proporcionaram uma diversidade de tipos de investigações em Educação e Ensino de Ciências, de tal forma que as pesquisas do tipo estado da arte (SALEM, 2012) confirmam a formação de professores como uma linha temática consolida na área de Ensino.

Villani et al. (2009) apontam o evento do lançamento do Sputnik como marco importante para o desenvolvimento da área de Pesquisa em Ensino de Ciências. Os autores indicam que esse momento representa um início de reformulações na formação dos professores de Física, uma vez que a "produção de materiais de ensino, baseados na competência científica, experiências de ensino e uma sensibilidade pedagógica dos autores [do PSSC]" (p.129) demandava professores alinhados com o projeto a fim de que se cumprissem os objetivos previstos.

Por outro lado, de forma mais geral, na história da formação docente no Brasil, em meio às mudanças nas leis e resoluções, levanta-se a questão relacionada à formação prática do professor, isto é,

da necessidade de preparar o futuro professor para a parte pedagógica surgiu a ideia de uma prática de ensino durante o período de formação, associada a um estágio durante o qual o aluno [licenciando] entraria em contato com uma turma e poderia acompanhar um processo real de ensino e aprendizagem, nas escolas de aplicação, verdadeiros laboratórios de pesquisa em ensino. Nestas Escolas de Educação haveria uma seção específica de Prática de Ensino, que seria responsável pela supervisão do estágio obrigatório, orientado e acompanhado pelo professor de prática de ensino e pelo professor regente de uma escola de aplicação (GOULART, 2002, p. 78).

Assim, após a Lei de Diretrizes e Bases (LDB) de 1961, o Parecer 292 do Conselho Federal de Ensino estabelece um currículo mínimo para parte pedagógica da Licenciatura em Física cuja Prática de Ensino passava a ser caracterizada como uma disciplina autônoma em relação à Didática, na forma de Estágio Supervisionado. Consequentemente, o Estágio Supervisionado passa a ser uma questão concreta e cada vez mais presente na formação inicial de professores, tendo sua carga horária aumentada de 200 para 400 horas a partir de 2002.

O aumento da carga horária de Estágio Supervisionado é uma mudança importante para a formação docente, cujo fator mais determinante são as Resoluções CNE/CP 01 e 02/2002, amparadas pelas Diretrizes Curriculares Nacionais para a Formação de Professores da Educação Básica, em nível superior, curso de licenciatura, de graduação plena (DCN), Parecer CNE/CP 18/2001. Com as DCN, "a Licenciatura ganhou, como determina a nova legislação, terminalidade e integralidade própria em relação ao Bacharelado, constituindo-se em um projeto específico", demandando a "definição de currículos próprios da Licenciatura 
que não se confundam com o Bacharelado ou com a antiga formação de professores que ficou caracterizada como modelo '3+1'"' (BRASIL, 2001, p.6).

No rumo das mudanças, recentemente as novas DCN (BRASIL, 2015) não apresentam alterações na carga horária do Estágio Supervisionado, mas trazem, entre outros, dois novos elementos (i) o impedimento da redução da carga horária para licenciandos que já atuam como professores da Educação Básica, exceto para aqueles que estão cursando a segunda licenciatura; (ii) um maior protagonismo da Escola de Educação Básica na formação docente para promover melhor interação entre a Universidade e a Escola ${ }^{2}$.

Assim, Pimenta e Lima (2005/06) defendem o Estágio Supervisionado "como um campo de conhecimento, o que significa atribuir-lhe um estatuto epistemológico que supera a tradicional redução à atividade prática instrumental" (p.6). Por sua vez, Gatti (2014) indica, como um dos resultados de uma ampla pesquisa sobre formação docente, que o Estágio Supervisionado se encontra desarticulado, sem planejamento e sem apoio institucional. A autora afirma que os Estágios "não explicitam as formas de relação com a rede escolar e não oferecem condições para um acompanhamento efetivo por parte de docentes que são designados para sua supervisão" (p. 40-41). Em outras palavras, Gatti (2014) evidencia a frágil relação entre a Universidade e a Escola no contexto do Estágio Supervisionado.

Da mesma forma, Lüdke (2009), ao investigar a relação da profissão docente, torna mais explícito a falta de articulação entre a Universidade e a Escola para o desenvolvimento do Estágio Supervisionado. No mesmo artigo, a autora ainda mostra a desarticulação entre as Faculdades de Educação e os Institutos, por exemplo, de Física; e defende a promoção da pesquisa em ensino como uma das formas de superação das desarticulações. Em outro texto, Lüdke (2013) apresenta o resultado de algumas investigações desenvolvidas pelo seu grupo de pesquisa, evidenciando diversos aspectos do Estágio Supervisionado, como: o papel do estagiário em seu próprio estágio, o qual se encontra diversas vezes apenas como observador no fundo da sala; o papel do supervisor e do orientador do estágio e o distanciamento entre eles; o papel das Secretarias de Educação e seu distanciamento do estágio supervisionado, entre outras.

Calderano (2014), após ampla análise de dissertações e teses defendidas na área de Educação, propõe eixos estruturadores, relacionados aos agentes do estágio (orientador, supervisor e estagiários), suas concepções e suas funções. Sua conclusão é que "de modo abrangente (...), podem ser destacadas a pulverização e a inorganicidade de concepções

\footnotetext{
${ }^{2}$ Neste caso, é possível perceber no instrumento de avaliação dos cursos de Licenciatura, revisado em abril de 2016, com a inclusão de indicadores que avaliam a relação da Universidade com a rede de Educação Básica; a relação entre os agentes do Estágio; e a relação entre teoria e prática (BRASIL, 2016).
} 
teórico-práticas sobre estágio curricular" (p. 59). A autora também identifica a "urgência de se dar mais atenção às relações estabelecidas entre universidade e escola e desenvolver um olhar mais atento ao professor da escola [de educação] básica" (ibid).

Considerando o estatuto epistemológico defendido por Pimenta e Lima (2005/06), os resultados de Gatti (2014) e as mudanças ocorridas na legislação, em especial nos últimos 15 anos, concluímos ser cada vez mais necessário inserir o Estágio Supervisionado na agenda da pesquisa em Educação e em Ensino de Física como parte das investigações sobre a formação docente.

Dessa forma, o nosso trabalho se insere no campo de pesquisa sobre formação inicial de professores de Física que traz a temática do Estágio Supervisionado como elemento de investigação e análise, sendo parte de uma pesquisa mais ampla de doutorado (SILVA, 2013). O objetivo deste artigo é apresentar e discutir, à luz da Teoria da Atividade, o episódio da atividade de confeccionar o roteiro de experimentos levados para escola pelos estagiários, alunos da disciplina de Práticas em Ensino de Física. A disciplina é obrigatória para alunos da Licenciatura em Física de uma universidade pública estadual, contendo 100 horas de carga horária de Estágio Supervisionado.

Mostraremos a gênese da atividade enquanto planejamento da equipe pedagógica, as modificações nas atividades a partir de uma discussão entre a professora e os licenciandos, bem como a mudança e a nova proposta que emerge de um processo coletivo entre os licenciandos e a professora. Vamos defender a ideia de que as mudanças ocorridas no decurso da atividade culminando com a nova proposta estão relacionadas com a vivência dos licenciandos na escola. As nossas considerações finais apontam para a relação Universidade e Escola como um sistema de atividades (ENGESTRÖM, 2001), com o estabelecimento de um objeto comum ao sistema como uma forma de melhor interação entre as duas instituições.

\section{Metodologia}

A nossa pesquisa foi conduzida baseada em uma abordagem qualitativa, uma vez que a sua finalidade essencial é "documentar em detalhes a conduta de eventos diários e identificar os sentidos que cada evento tem para aqueles que tomam parte deles e para aqueles que os testemunham" (ERICKSON, 2012; p. 1451, tradução nossa). Dentro da mesma abordagem, segundo Lüdke e André (1986), apontamos ainda outros dois aspectos: (i) a disciplina de Práticas em Ensino de Física é o locus da pesquisa e, portanto, fonte direta dos dados; (ii) os dados são descritivos, coletados por meio de registros do pesquisador e a videogravação. 


\section{(i) A disciplina de Práticas em Ensino de Física como locus da pesquisa}

O locus da pesquisa é na universidade, mais especificamente na disciplina de Práticas em Ensino de Física, oferecida pelo Instituto de Física, obrigatória para os alunos do curso de Licenciatura em Física de uma Universidade Pública Estadual. A disciplina de Práticas agrega 100 horas de Estágio Supervisionado, ficando a cargo da Faculdade de Educação as outras 300 horas, distribuídas em diversas disciplinas, entre elas Metodologia de Ensino de Física I e II. A estrutura da disciplina de Práticas é bem ampla e contém diversos elementos, contribuindo para uma dinâmica complexa que envolve diversos sujeitos nos dois contextos em que a disciplina estava inserida, a universidade e a escola.

A disciplina contava com a participação dos seguintes sujeitos: a professora, docente do Instituto de Física; dois educadores, pós-graduandos; duas monitoras, graduandas; os licenciandos; e um técnico de laboratório para apoio aos docentes e discentes. Os professores da Escola de Educação Básica não participavam diretamente da organização do estágio e tão pouco os outros atores da escola, como por exemplo, os alunos e coordenadores/diretores. Inclusive o professor de Física responsável pela turma na qual atuavam os licenciandos tinha uma participação muito restrita nesse processo (por exemplo, definindo o tema relativo aos experimentos).

A seguir a apresentação das três situações em que os licenciandos tinham participação:

(a) A aula era o momento em que toda a classe (a professora, os educadores, as monitoras e os licenciandos) estava reunida para: (1) discutir em conjunto sobre alguma questão de ordem burocrática (organização dos horários de visita à escola); (2) comentar o relato de alguns licenciandos sobre os eventos ocorridos na escola; (3) debater algum conteúdo de Física e temas de Ensino de Física relevantes (por exemplo, as características e o papel da experimentação nas aulas de Física). A aula tinha frequência quinzenal, pois alternava com o estágio na escola.

(b) A oficina era o momento mais específico para preparar o que seria desenvolvido pelos licenciandos nas aulas de Física na Escola. Para isso, foram criadas várias oficinas de duas horas cada, distribuídas ao longo da semana, nas quais os licenciandos em duplas escolhiam um horário para participarem. As oficinas também eram quinzenais, alternando com o estágio. Os educadores e as monitoras eram os responsáveis por acompanhar os licenciandos nas oficinas, com orientações sobre a montagem dos kits experimentais que seriam levados para escola. 
(c) O estágio ${ }^{3}$ era o momento em que os licenciandos iam para a escola desenvolver aquilo que fora preparado na oficina. Dessa forma, a ida à escola era a cada 15 dias, na semana posterior à oficina, cuja dinâmica durou todo o ano letivo. Todo o material que eles prepararam na semana anterior já havia sido deixado na escola pela equipe de educadores. Ressalta-se que no início do ano a professora da disciplina de Práticas procurou alguns professores supervisores das escolas públicas de Ensino Médio e uma de Ensino Fundamental ao redor do campus, para os quais apresentou um conjunto de experimentos. Os professores indicavam aqueles que gostariam de ver desenvolvidos em suas turmas ou então eles indicavam outros tipos. Neste caso, a equipe da disciplina contava com um técnico que produzia os kits que ainda não existiam.

\section{(ii) A coleta de dados}

Os dados apresentados neste artigo foram coletados especificamente nas aulas na Universidade, constituindo-se nas transcrições das falas dos sujeitos e nas descrições de eventos e situações. O recurso da gravação em vídeo foi utilizado porque fornece informações mais detalhadas da dinâmica das aulas. Trata-se, portanto, de uma técnica bastante útil e importante para a análise mais pormenorizada dos eventos e falas dos sujeitos, impasses e problemas durante a resolução das tarefas, momentos de silêncio que ocorrem durante as aulas (CARVALHO, 2006).

É importante ressaltar que não houve coleta de dados durante a realização do Estágio nas Escolas parceiras. Apenas na Universidade, seja nas aulas (cujos dados aqui apresentamos e analisamos), seja nas oficinas (apresentado e analisado em nosso trabalho de doutoramento).

Antes do início da coleta de dados, o pesquisador, que exercia também a função de educador, foi apresentado aos licenciandos como alguém que estaria nas duas funções. No dia em que a filmadora foi instalada na sala de aula, foram explicados os objetivos da pesquisa, enfatizando que as imagens seriam usadas somente pelo pesquisador para fins do estudo. Foi informado também que a professora da disciplina não teria acesso aos vídeos e não haveria nenhum tipo de interferência na nota final dos licenciandos, os quais assinaram termos de

\footnotetext{
${ }^{3}$ No início do ano letivo, a professora durante as aulas dividiu os licenciandos em duplas e apresentou as escolas parceiras, nas quais o Estágio deveria ser desenvolvido. O Estágio naquele ano foi desenvolvido em 7 Escolas Estaduais de Ensino Médio, nos três turnos e uma Escola Municipal de Ensino Fundamental. Ao longo do ano, devido aos problemas que serão apresentados na seção de análise, a professora estabeleceu contato com mais uma Escola Estadual de Ensino Médio. Todas as escolas eram próximas à Universidade. Contudo, não realizamos coletadas de dados nas salas de aula em que o Estágio era desenvolvido. Os licenciandos relatavam suas vivências durante as aulas na Universidade em que era possível os licenciandos narram suas frustrações bem como seus acertos.
} 
consentimento. Dessa forma, cumprimos uma etapa importante da pesquisa, apontada por Erickson (2012) referente aos cuidados éticos e de negociação de entrada no campo.

\section{A Teoria Sócio-Histórica da Atividade}

Devido às suas potencialidades, entre elas a centralidade nos processos de transformação e de criatividade dos sujeitos (STETSENKO, 2005), o uso da Teoria da Atividade (TA) tem aumentado expressivamente nas últimas duas décadas e meia, sobretudo, nas pesquisas em educação.

Roth (2004), em um editorial para a revista Mind, Culture and Activity, traz uma citação de Yrjö Engeström do início da década de 1990, que diz ser a Teoria da Atividade "the best kept secret of academia". No entanto, no mesmo texto, Roth (2004) mostra que a frequência de citações da TA como palavras-chave "Activity Theory" aumentou na proporção de 10 vezes ao longo da última década do século passado. O autor alerta em seu epílogo que a TA não deveria ser mais mantida em segredo.

Na mesma perspectiva, Nussbaumer (2011) mostra o uso, ainda que limitado, mas cada vez crescente da TA em pesquisas qualitativas em Educação envolvendo os Ensinos Fundamental e Médio. No Brasil, embora não haja uma pesquisa sistemática do estado da arte acerca da TA, na literatura de nossa área encontramos alguns trabalhos que parecem apontar a tendência ao uso da TA cada vez mais recorrente, como ressaltam Camillo e Mattos (2014).

A Teoria da Atividade tem os seus pressupostos fundamentais no pensamento de Vigotski, que prima pela relação do processo histórico como princípio edificante da psicologia humana. A tese vigostkiana possui duas hipóteses básicas: (i) "as funções psíquicas do homem são de caráter mediatizado"; (ii) "os processos interiores intelectuais provêm de uma atividade inicialmente exterior, interpsicológica" (LEONTIEV, 1978, p.164).

Leontiev (1978) afirma que a relação entre sujeito e objeto se dá por meio da atividade humana que é marcada por seu aspecto coletivo. Segundo o mesmo autor, a atividade se desenvolve através das ações - os processos em que o motivo e o objeto não coincidem - e operações, os modos de execuções de uma ação.

Engeström (1987) propõe um modelo de atividade (Figura 1) no qual se considera que a relação entre o sujeito e o objeto é mediada tanto por instrumentos/artefatos, quanto pelo ambiente sócio-histórico-cultural. Em seu modelo, ele coloca em evidência as relações entre o indivíduo e o seu coletivo. Nesse sentido, a mediação entre sujeito e objeto ocorre por meio de instrumentos e pela comunidade na qual pertencem com seus valores, regras e a divisão do trabalho. 


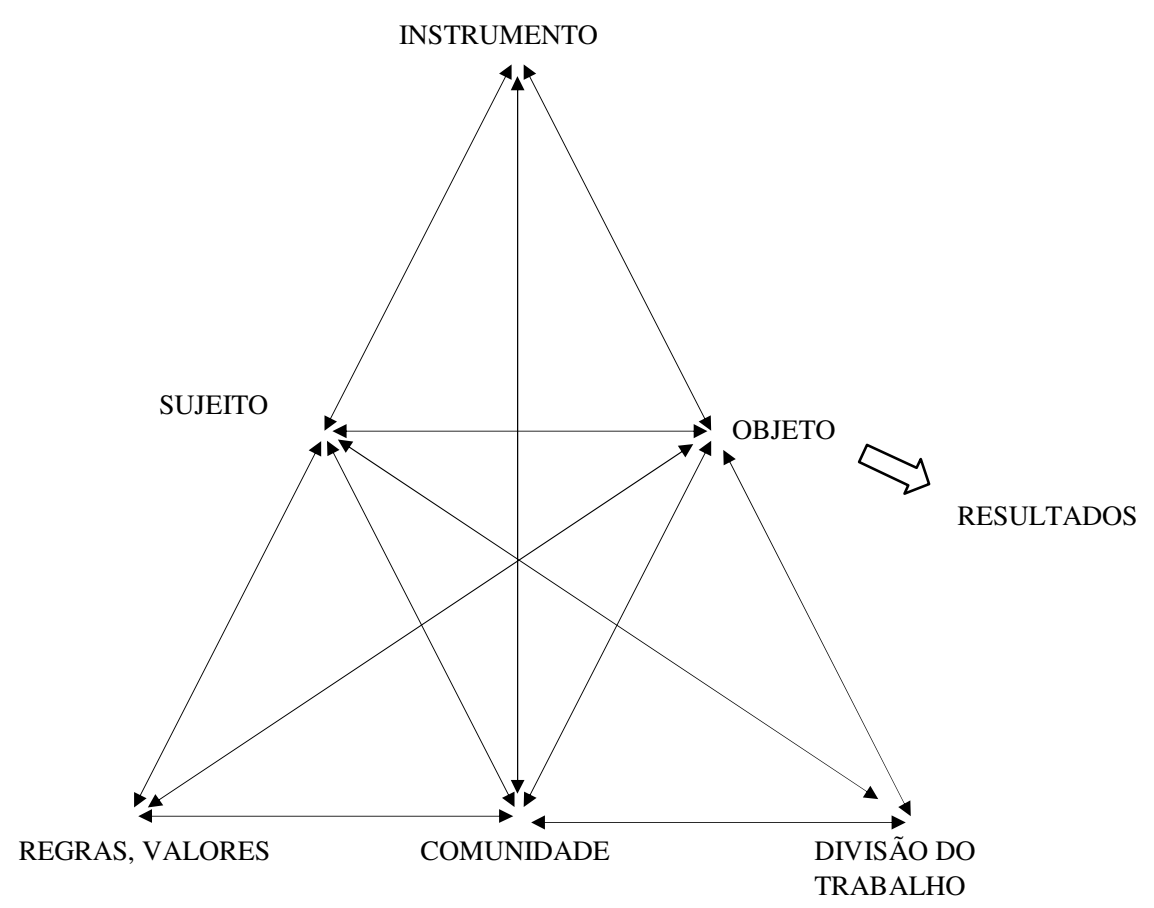

Figura 1 - Modelo da estrutura da atividade humana de Engeström (1987).

Uma apresentação de como este modelo auxilia para a compreensão da atividade analisada será apresentada durante a própria análise do caso.

\section{A atividade de confeccionar o roteiro: proposta, os problemas e a mudança e a nova proposta}

A proposta de os licenciandos confeccionarem o roteiro dos experimentos nas escolas surgiu em uma das reuniões de trabalho da equipe pedagógica (a professora da disciplina, os educadores e as monitoras), após uma avaliação sobre os trabalhos realizados até aquele momento, quando a disciplina chegava ao fim do primeiro semestre ${ }^{4}$ e já havia ocorrido uma rodada de idas à escola. Nessa reunião foi apontada a necessidade de os licenciandos terem uma participação mais ativa e efetiva no processo de elaboração dos kits que eram levados para escola. Então, surgiu a ideia de oferecer aos licenciandos a possibilidade de confeccionar os roteiros do terceiro bloco de experimentos, isto é, de os próprios licenciandos elaborarem os roteiros.

De acordo com a professora, o grupo de licenciandos do ano anterior (2009) também demandava maior participação. Nesse caso, eles tinham menor participação ainda do que o grupo de 2010, uma vez que naquele ano as oficinas não tinham horários pré-definidos como em 2010, e nem mesmo havia um local próprio para a preparação dos experimentos.

\footnotetext{
${ }^{4}$ Ressaltamos que a disciplina é anual.
} 
Em 2009, havia apenas uma sala aula à disposição onde os experimentos ficavam expostos e as duplas de licenciandos deveriam comparecer em algum dos horários disponibilizados pelos educadores e monitores para repassar o experimento que seria levado para o estágio. Os licenciandos não tinham participação nem na montagem das caixas nem na elaboração dos roteiros, os quais eram importados da versão anterior da disciplina de Práticas ou criados pelos monitores e educadores. Dessa forma, naquele ano de 2009, o único contato com o material a ser usado no estágio pelos licenciandos era na escola, o qual já havia sido levado por um dos educadores.

Em 2010, a equipe de trabalho optou por definir horários em que os licenciandos deveriam estar presentes para o planejamento de seu trabalho na escola, criando assim as oficinas. Essa organização proporcionou maior participação, ou pelo menos, maior presença dos licenciandos nas oficinas. Contudo, os primeiros experimentos tinham os roteiros prontos provenientes do ano anterior, os quais foram aproveitados para evitar o desperdício, já que alguns deles tinham muitas cópias. A consequência da criação das oficinas foi a possibilidade de participação no processo de elaboração dos kits. Em paralelo a essas mudanças, a disciplina ganhou um espaço próprio para o desenvolvimento das oficinas, o Laboratório Didático-Pedagógico, o qual foi equipado ao longo do ano de 2010. Durante as oficinas, os licenciandos tinham que testar o experimento de forma a prepará-lo para o seu desenvolvimento na escola, podendo, algumas vezes, opinar nos roteiros.

Então, como forma padrão de procedimento, uma cópia do roteiro era fixada sobre uma bancada servindo de matriz, na qual as duplas de licenciandos podiam deixar escrito o que gostariam de alterar ou acrescentar. Contudo, como foi dito, as sobras do ano anterior eram utilizadas e, portanto, levadas para a escola. Logo, os licenciandos não se sentiam contemplados no processo ou percebiam que todo o esforço de pensar um roteiro diferente era desperdiçado. É dentro desse contexto que surgiu a ideia de que o terceiro bloco de experimentos fosse preparado pelos licenciandos.

\section{A proposta}

A aula do dia 10/06/2010 foi praticamente a última do primeiro semestre que deveria manter a característica de relato e avaliação dos trabalhos de estágio. De fato, na aula seguinte, a diretora de umas das escolas parceiras foi convidada para conversar com os licenciandos, uma vez que a maioria dos que estagiavam nesse colégio participava da aula na turma do diurno. 
Logo no início, a professora Velma ${ }^{5}$ apresentou a proposta e as justificativas, baseando-se na experiência do ano anterior em que os licenciandos prepararam o último roteiro. A proposta para o ano em questão era que os três últimos roteiros fossem preparados pelos licenciandos. Na fala da professora, fica bem claro o que se esperava dessa tarefa.

\begin{tabular}{|c|c|c|}
\hline urno & Sujeito & Fala \\
\hline 1 & Velma & $\begin{array}{l}\text { A gente já conversou sobre isso, no ano passado os alunos } \\
\text { [licenciandos] reivindicaram a possibilidade de confeccionar os } \\
\text { roteiros que vão pra escola. E no ano passado o que foi feito foi a } \\
\text { confecção do último roteiro. Nesse segundo semestre... tem na } \\
\text { verdade sete experimentos e a última ida à escola é uma visita de } \\
\text { avaliação com a turma, que foi a proposta dos próprios professores. } \\
\text { Então, o que a gente está propondo esse ano é que vocês } \\
\text { confeccionem três atividades [experimentos] do último bloco. O } \\
\text { tema no último bloco é definido pelo professor. E aí dentro desse } \\
\text { tema vocês propõem três atividades experimentais ou... do tipo que } \\
\text { a gente vem fazendo. Mas pra dar tempo de vocês pensarem, } \\
\text { confeccionarem, testarem a atividade [o experimento] aqui e e } \\
\text { discutir com o professor a gente vai começar isso já. Então a ideia é, } \\
\text { ainda nesse mês de junho, sabendo quais são os temas que já estão } \\
\text { postados no stoa } 6 \text {, também já tem no stoa o [fórum] lugar para } \\
\text { vocês escreverem. Vocês já pensariam dentro do tema ideias sobre } \\
\text { as atividades e os conceitos que seriam explorados. Então, seriam } \\
\text { quinze dias para fazer isso. A complicação que existe é a seguinte, é } \\
\ldots \text {... algumas escolas têm várias turmas, por exemplo, o Andronico } \\
\text { tem várias turmas do primeiro ano. (...). A ideia não é fazer um } \\
\text { roteiro para cada dupla do primeiro ano. Mas é fazer um único } \\
\text { roteiro para todas as turmas do primeiro ano. Portanto, as duplas } \\
\text { vão ter que conversar entre si. (...). }\end{array}$ \\
\hline 2 & Marcos & Mas por que tem ser um único roteiro? \\
\hline 3 & Velma & $\begin{array}{l}\text { Porque senão a gente não consegue preparar kit, roteiro, né. Não é } \\
\text { só preparar o roteiro, preparar o kit, levar o kit pra escola, né, se a } \\
\text { tiver ... }\end{array}$ \\
\hline
\end{tabular}

${ }^{5} \mathrm{O}$ nome da professora bem como os dos demais licenciados são fictícios.

${ }^{6}$ Plataforma moodle utilizado pela Universidade para interações virtuais entre professor, monitor e alunos. 
Ao longo da apresentação da proposta, a turma como um todo permanecera em silêncio, sem muitas questões, com exceção de Marcos cujas perguntas às vezes soavam adversativas. Outros também faziam perguntas que pareciam retóricas, isto é, repetia o que Velma já tinha falado para verificar se haviam entendido.

31 Velma Vamos explicar mais uma vez, no dia 30/08, vocês vão apresentar a atividade da sexta [série], sei lá, para o pessoal do primeiro colegial. E aí troca!

32 Lic 1 As três atividades?

33 Pesq As três não vão dar, né!

34 Velma É, provavelmente a primeira.

35 Juca Ah! Então a gente vai fazer a atividade com outro grupo?

36 Velma Com outro grupo! Então você já traz o roteiro, um pré-material, que já tem na oficina. Vocês já vão conversar nas oficinas se algum material não existir aqui, a gente já compra. E aplica [para outro grupo] pra poder (...) criticar a própria atividade. Ver que ajustes vocês vão fazer e vocês podem melhorar o roteiro a partir, por exemplo, dessa aplicação.

37 Juca A gente vai postar os objetivos, foi como a senhora falou. Então por exemplo, eu tenho uma sétima, vão ser meio que universalizado os roteiros, os experimentos, né?

38 Velma Isso!

39 Juca Então, por exemplo, eu coloco lá os objetivos, eu e minha dupla, aí a outra sétima tem outra dupla também. Aí põe outros objetivos

40 Velma Aí vocês vão ter que conversar!

A professora explicou, então, com mais detalhes e apresentou um cronograma da proposta, logo após Marcos apresentou sua contraproposta.

41 Marcos É que eu acho que é assim, é uma ideia, mais complexa de aplicação. Que seria o seguinte, na logística que a gente está fazendo [na disciplina], a gente está levando simultaneamente a mesma experiência para vários alunos e para várias turmas. E depois a gente pode até comentar os resultados disso, mas eu imagino que dependendo da situação ou do projeto que a gente tenha, daria para colocar na mesma turma experiências diferentes em grupos diferentes, depois é só fazer o revezamento dos kits entre os grupos.

42 Velma Como assim revezamento?

43 Marcos Então, se a gente tivesse três kits. Vamos extrapolar para 5, vai!

44 Velma 5 kits pro primeiro colegial do Andronico?

45 Marcos Só que os 5 kits não precisam ser idênticos. (...) E aí pegar de uma experiência pra outra, agora eu não sei daria uma aula, mas pode acabar na outra. Mas é fazer com que esses kits rodassem. Então não precisa comprar muitos kits, só que poderia trabalhar com o mesmo orçamento, mas com kits um pouquinho mais complicado talvez. Só que aí tem que fazer o seguinte, as pessoas que já fizeram têm que trocar a experiência [...] Então, o grupo que fez semana passada troca.

A ideia principal de Marcos era fazer um rodízio de experimentos durante uma aula. Para isso, diferentes kits seriam levados para escola; os alunos seriam dispostos em grupos de tal forma que cada grupo passaria pelos experimentos. A sua ideia é totalmente diferente da maneira como os experimentos eram levados para escola, isto é, em vez de levar um kit com 
material para até 10 grupos em sala, haveria menor quantidade de material e maior diversidade de experimentos. Marcos ainda tentou pensar na articulação dos experimentos com a aula, no sentido da relação do experimento com o conteúdo. A professora não deu continuidade à proposta nem à sua discussão.

\section{Os problemas}

A aula do dia 02/08/2010 foi a primeira do segundo semestre. No início, a professora deu algum tempo para os licenciandos se acomodarem na sala de aula, pois no horário previsto para início da aula poucos haviam chegado. Depois de alguns minutos, a professora, então, iniciou formalmente a aula, dando as boas-vindas aos licenciandos. Logo em seguida, ela já anunciou os problemas que surgiram com a mudança de semestre.

51 Velma Então, eu não sei se tem alguém aqui com problemas... a gente tem que fazer alguns acertos finais, que ainda dependem da escola. Porque é assim, o Andronico mudou o horário... todas as escolas mudaram o horário. Mas isso não significa que mudou o horário de vocês. O que eles fizeram foi, por exemplo, você estava com dois terceiros e agora vai ficar com um primeiro e um segundo, tá? Mudaram as turmas naquele mesmo horário. Mas não foram mudanças grandes

Como podemos ver na fala inicial da professora, o problema foi a mudança de horários da escola, o que não costumava acontecer, pelo menos não tinha ocorrido no ano anterior. A mudança de turmas se tornou, então, o grande problema para o desenvolvimento da proposta. Vale lembrar que um dos requisitos da proposta era que os licenciandos se articulassem em grupos por série e por escola para discutirem os objetivos e temas dos experimentos, já que haveria um roteiro único para cada série. Assim, mudar de turma significava que deveria recomeçar o processo que já teria sido iniciado em junho.

Em seguida, Fabrício, um dos licenciandos, apresenta à professora Velma outro problema. Ele e sua dupla faziam o estágio em turmas da EJA, o que implicava em, necessariamente, mudança de turma. Assim, a proposta atual não cabia para os alunos que estagiavam na EJA. Ressaltamos que esse problema não foi pensado pela equipe pedagógica ou apontado por algum licenciando quando a proposta foi feita no final do semestre anterior. A solução imediata da professora foi conversar com as duplas de licenciandos da EJA em separado.

\section{A mudança e nova proposta}

No final do primeiro mês de aula do segundo semestre letivo, em 30/08/2010, a professora Velma fez o anúncio de que a proposta de os licenciandos confeccionarem os roteiros do terceiro bloco estava cancelada. Ela primeiramente comentou que não tinha visto 
muita movimentação nos fóruns criados do stoa para as postagens dos temas e objetivos. E em seguida, atribui o motivo do cancelamento a outros fatores ligados a escola, especialmente às mudanças de horários.

64 Velma Eu entrei nos fóruns agora e não está tendo discussão, então eu acho que está mal encaminhado (...).

65 Velma Pois é, eu acho que é assim, foi uma combinação de fatores, né. Essa mudança de horário no segundo semestre que não acostumava ocorrer, ocorreu por conta dessa... quer dizer, pelo menos na escola, né. Vocês ... alguns de vocês tiveram mudança de horários, mas não foram muitos. Mas a escola normalmente não tem mudança de horários no segundo semestre. Pelo menos não teve no ano passado, não sei se é assim normalmente. Parece que esse ano a forma de contratação, parece que o governo conduziu... a secretaria de educação atrapalhou terrivelmente o segundo semestre. Então, tem esse lado. Tem o outro lado que ou faltou incentivo da nossa parte ou sei lá o que, os fóruns não caminharam. Eu estou propondo aqui, (...), que não vai rolar o bloco 3. Talvez o Andronico, se o pessoal que tiver mais bem encaminhado quiser fazer. Pra isso acontecer, precisava hoje já estar pronto, pra gente poder conversar com o professor, vocês conversarem com o professor. E... tem que ter um prazo. Então... diante dessa situação minha proposta é que a gente deixe... talvez o Andronico, Virgilia se for a última experiência

Uma conjunção de fatores teria contribuído para a não realização da proposta. A professora apontou, inicialmente, um fator externo como o principal responsável, isto é, a escola que havia mudado os horários das aulas no segundo semestre. Essa mudança não estava prevista porque não costumava acontecer. Porém, parece-nos que Velma foi bem enfática em buscar fatores internos pelos quais a proposta não teria logrado. Ela destacou a baixa participação dos licenciandos nos fóruns do stoa e uma possível falta de incentivo por parte da equipe de trabalho (a própria professora, os educadores e as monitoras).

Dessa forma, a combinação de fatores, como Velma assinalou, a teria levado ao cancelamento da proposta. Em sua fala destacada no turno 65 nos parece que a sua decisão fora tomada naquele instante, sem nenhuma discussão prévia com a equipe pedagógica na reunião de trabalho. Mesmo tendo desistido da proposta como um todo, ela ainda cogita a possibilidade de que pelo menos os licenciandos do Andronico e Virgília elaborassem a última experiência.

A partir daí, a aula seguiu como era de costume, com relatos e avaliações dos licenciandos sobre os seus trabalhos de estágio. Porém, nesta aula, a professora foi mais enfática ao pedir que os licenciandos fizessem uma avaliação da escola, nem tanto da disciplina. É, então, em meio a essa conversa que a nova proposta surge. 
66 Velma Gente eu estou aqui quebrando a cabeça pensando em como vou organizar hoje. Porque o que deveria acontecer, não vai acontecer. E... eu estou com um pouco a sensação, eu tenho discutido com Educador 1 e o Educador 2 que as coisas não estão indo muito bem. O Educador 1 me fala o contrário, ele acha que está indo bem melhor do que o ano passado, comparativamente. E quando eu chego e vejo que o horário da escola mudou, e outra fala que não deu pra dar aula, estou com uma sensação terrível que as coisas estão meio desastrosas. Não sei se vale a pena fazer um... já que está todo mundo junto aqui... dar uma passada nisso e ver aonde estão os problemas. Já que a gente não vai trabalhar no terceiro bloco, vamos trabalhar em algumas questões que sejam mais complicadas aí. Então, eu estou com a sensação de que está dando muito errado as idas na escola, estou com a sensação de que os experimentos nem sempre estão funcionado ou as explicações estão muito complicadas e os meninos [os alunos da escola] não estão entendendo nada, estão escrevendo e a gente não consegue nem ler ... Como é que está essa situação? Vamos dar uma passada geral aqui?

(...)

67 Lucio A gente tinha preparado um experimento aqui, um roteiro, e tal, e parecia que estava bom. Só que aí a gente na escola e a gente abriu a caixa e era outro equipamento, outro roteiro. Se bem que era sobre a mesma coisa, sobre circuito elétrico.

(...)

68 Túlio [que fazia parte do grupo de Leon e Lucio]: Também estava muito grande, até o Beto [professor] falou que era para fazer uma parte só, porque as duas não iam dar, que era só circuito em série. $\mathrm{O}$ em paralelo era para ficar para uma outra vez.

69 Lucio É a sugestão dele era para deixar para a próxima aula.

70 Leon [fazia parte do grupo de Lucio e Túlio] Sobre o experimento, eu achei assim, tinha muito conteúdo a ser trabalhado. Porque, usar um multímetro não é uma coisa tão simples. Porque você ensinar a pessoa como vai ligar um tipo em série ou em paralelo, não é algo muito óbvio. A gente, sobre o circuito das lâmpadas, achou que tem muitas coisas que são obscuras na hora de montar o circuito. Mesmo o porta lâmpadas, aquilo não é muito claro, que aquelas lâmpadas estão em série porque a lâmpada vai e volta, vai e volta e elas parecem paralelas. E ... e aí quase todo circuito é assim, é quase sempre difícil de ver. É difícil de serem trabalhadas e enxergar (?). (...) Porque a gente sentiu que muita coisa que a gente fosse parar para explicar, e muito difícil desenvolver parte do roteiro ou completo.

Em seguida, a pedido da professora Velma, outro licenciando comentou que os alunos da escola em que estagiava não tinham a teoria para entender o que estava acontecendo no experimento. No caso, era falta de conhecimento sobre o átomo de Rutherford. Assim, motivados por esse comentário, outros licenciandos disseram que eles também estavam enfrentando o mesmo problema do desencontro entre o roteiro levado para o estágio e o conteúdo que estava sendo desenvolvido. O caso mais enfático foi o de duas licenciandas cujo roteiro que elas preparavam nas oficinas era sobre termodinâmica e o professor estava abordando planetas nas aulas de Física. A partir desses relatos, Velma parece desabafar com a turma. 
79 Velma (...) como é que isso ainda está acontecendo, já final de agosto? Quer dizer, vocês foram lá para dar duas só, pra participar de duas aulas. O professor vai lá ... dá quarenta, cinqüenta, sessenta aulas nesse esquema. Então é uma realidade absurda que a gente vive. Isso é nas escolas, nos bairros. E isso não é lá em Cap Red. Porque às vezes alguém fala 'não, porque a escola é na periferia'. Não tem essa de periferia. Aqui do lado. Está assim a escola pública. Então você tem razão [fala para Fabrício]. Agora por outro lado é um treinamento. (...) O Beto dá aula em três escolas diferentes, então não tem jeito da educação estar bem com isso, né? Então, vocês chegam, os meninos não sabem o que é átomo, então vai explorar outra coisa! (...) Tem que explorar o que é possível explorar com a turma. Provavelmente, o Digão com aquela turma da manhã consegue explorar mais coisas lá do que vocês na turma do Beto. Até mesmo porque o Beto dá aula em três colégios e a Rosa [professora que acompanha Digão] só lá [no Andronico], então não duvido que o trabalho dela seja melhor do que o do Beto, é natural que seja.

80 Educ Só um comentário rápido, uma nota de rodapé. Digão na semana passada conseguiu personalizar o roteiro. E hoje já teve mais gente que fez isso (...).

81 Velma Então talvez seja bem mais interessante em vez da gente investir nesse terceiro bloco, seja melhor investir em personalizar os roteiros, adequar eles às turmas que você tem. Não é? Porque aí vocês já conhecem. Porque senão a gente quer fazer tudo e por fim não acaba fazendo nada.

Essa sequência de falas termina com a professora fazendo uma nova proposta: personalizar o roteiro e não mais confeccionar, nos moldes em que ela já havia dito. O que nos parece importante apontar é que a gênese da nova proposta não se deu na reunião de trabalho, nem em um planejamento da disciplina, em meio a uma discussão entre a professora, educadores e monitoras. A proposta surgiu a partir de situações concretas vivenciadas pelos licenciandos durante os trabalhos de estágio.

$\mathrm{Na}$ verdade, a prática de personalizar o roteiro já estava sendo realizada por algumas duplas de licenciandos, prática esta que foi generalizada para a maioria das duplas. É importante ressaltar que no segundo semestre letivo o laboratório didático-pedagógico onde ocorriam as oficinas estava bem mais estruturado do que no início do ano letivo, facilitando a personalização dos roteiros. Assim, quando foi mencionado na aula que outros licenciandos estavam elaborando roteiros personalizados, a professora encampou a ideia e a transformou em proposta de atividade. Temos aí uma nova atividade: personalizar os roteiros.

Para personalizar os roteiros, cada dupla teria a possibilidade real de altera-los, levando em conta as especificidades das turmas em que estagiavam. Essa era uma proposta exequível, uma vez que o Laboratório Didático-Pedagógico já estava equipado com alguns computadores. Por outro lado, personalizar o roteiro não implicaria em personalizar os kits, não onerando, assim, a equipe de trabalho, inclusive o responsável pela logística da organização material e pela entrega nas escolas.

Então, a proposta de personalizar os roteiros enfatiza dois aspectos importantes: 
- $\quad$ Surge a partir da vivência dos licenciandos na escola (turnos 80 e 81);

- Implica na autonomia para preparar o roteiro de acordo com a realidade da turma.

Como descrevemos anteriormente, o cronograma proposto não se realizou e não houve a participação nos fóruns do stoa como era esperado. Porém, o problema maior foi o excessivo número de mudança dos horários das escolas, em especial no Andronico, onde um razoável número de licenciandos realizava o estágio. Por causa dessa mudança, a situação se tornou semelhante à do início do ano, quando a professora estava organizando as duplas de licenciandos e os horários do estágio. Como consequência, a professora Velma cancelou a atividade de confeccionar os roteiros do terceiro bloco, já que não haveria tempo hábil para tal.

\section{Considerações sobre as aulas}

No quadro 1 a seguir apresentamos uma síntese das aulas, a fim de facilitar a compreensão do processo até aqui apresentado. Vamos nesta seção fazer as nossas considerações sobre as aulas, usando a Teoria da Atividade para a elaboração da análise.

Quadro 1 - Sequência de aulas referente à atividade de confeccionar o roteiro e uma descrição sumária dos acontecimentos

\begin{tabular}{|c|l|}
\hline Dia & \multicolumn{1}{c|}{ Momento/Características } \\
\hline $10 / 06$ & $\begin{array}{l}\text { Proposta - Pode ser considerada a última aula do semestre. A professora Velma faz } \\
\text { a proposta da atividade de confeccionar o roteiro do terceiro bloco. A outra parte da } \\
\text { aula consiste nos relatos dos licenciandos sobre o estágio }\end{array}$ \\
\hline $02 / 08$ & $\begin{array}{l}\text { Problemas - Primeira aula do segundo semestre. Devido às mudanças de horários } \\
\text { das escolas e falhas na organização, a atividade sofreu prejuízos. Professora Velma } \\
\text { tentou resolver esses problemas. Depois os licenciandos se dividiram em grupos } \\
\text { para dar continuidade à atividade }\end{array}$ \\
\hline $30 / 08$ & $\begin{array}{l}\text { Mudança e nova proposta - Aula em que os licenciandos deveriam apresentar } \\
\text { suas propostas de roteiros. Como ninguém o fez, a professora Velma cancelou a } \\
\text { proposta. Em seguida, iniciou-se o relato dos licenciandos, apontando dificuldades } \\
\text { na realização das experiências e também iniciativas para sua solução; momento em } \\
\text { que Velma lançou a proposta de personalizar o roteiro }\end{array}$ \\
\hline
\end{tabular}

\section{A atividade docente de confeccionar o roteiro}

A atividade de confeccionar o roteiro pode ser considerada de duração de médio prazo, compreendida basicamente no intervalo de tempo descrito na seção anterior e organizada por aqueles momentos: a proposta, os problemas, as mudanças e a nova proposta. De acordo com Roth e Lee (2007), os teóricos da atividade usam a representação do triângulo da Figura 1 para explicitar as mediações entre sujeito, objeto e os recursos material e social que são salientes na atividade. Os autores enfatizam que essa representação por tríades de mediação da Teoria da Atividade serve como uma forma heurística de conduzir a análise de situações 
concretas. Dessa forma, torna-se importante especificar o uso do termo 'atividade'. Os mesmos autores dizem que

para elaborar alguns aspectos fundamentais da Teoria da Atividade usados no triângulo-heurístico, o termo atividade não deve ser igualado com eventos relativamente curtos com pontos inicial e final bem marcados (característicos das tarefas escolares), mas um envolvimento complexo da estrutura mediada e coletiva do agenciamento humano (p. 197, tradução nossa).

A atividade de confeccionar o roteiro, enquanto uma proposta da professora, está representada na Figura 2, tendo como sujeito os licenciandos.

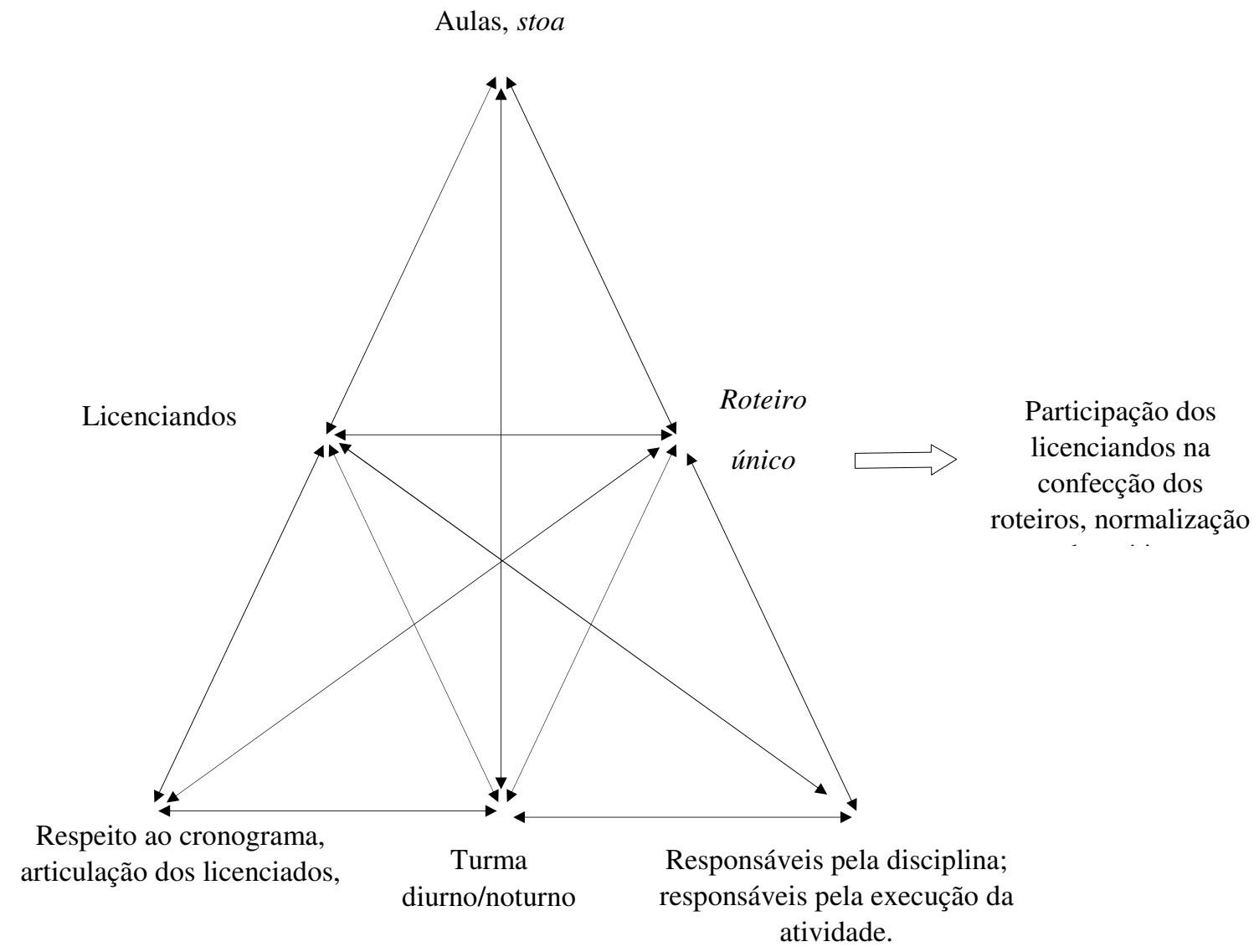

Figura 2: Modelo da atividade de confeccionar o roteiro proposta pela professora.

De acordo com Leontiev (2009), o objeto, "da atividade aparece em duas formas: primeiro, em sua existência independente, comandando a atividade do sujeito, e segundo como uma imagem mental do objeto, como um produto da "detenção" dos sujeitos das suas propriedades [do objeto]" (p.3). Por outro lado, "o objeto aparece para o sujeito primeiro como em forma de tarefas, problemas e ações discretas", cuja descoberta dos objetivos tornase fundamental para a realização da atividade (ENGESTRÖM, 1987, p. 78). Então, dizemos que o roteiro único apresenta-se como o objeto da atividade, no que se refere à sua proposição.

O roteiro único é uma idealização do objeto no sentido que é uma imagem mental, "cuja real função é orientar o sujeito no mundo objetivo", como definiu Leontiev (2009). O 
roteiro único é, portanto, o objeto da atividade e o seu motivo. Enquanto que o resultado a ser alcançado deve ser fruto do próprio processo de desenvolvimento da atividade, pois é na atividade que "ocorre uma transição do objeto refletido na imagem subjetiva, em ideal; ao mesmo tempo, é na atividade que a transição é alcançada do ideal para os resultados da atividade objetiva, para seu produto, para o material" (ibid, p.3). Então, a confecção dos roteiros (roteiro único) e a participação dos licenciandos na disciplina se constituem no resultado esperado para esta atividade. Vale lembrar que se trata do resultado esperado pela professora e a equipe pedagógica em relação aos licenciandos.

Os instrumentos que os licenciandos dispunham para a realização da atividade eram as próprias aulas, uma vez que nestas deveriam ocorrer a apresentação dos roteiros preparados pelos licenciandos; e a plataforma moodle, o stoa, que deveria ser usada para as trocas de ideias e as proposições dos objetivos para definir o tema dos experimentos do último bloco.

No que se refere a parte inferior do triângulo, as regras, que constituem a mediação entre os sujeitos (licenciandos) e sua comunidade (a própria turma), são o conjunto de medidas estabelecidas pela professora no momento em que ela apresenta a proposta aos licenciandos. Assim, a articulação entre os licenciandos que faziam o estágio na mesma série/escola e o respeito ao cronograma se apresentam como as principais regras. Por outro lado, a divisão do trabalho, que é a mediação entre a comunidade e o objeto, ocorre entre as diferentes funções que os sujeitos desempenham no âmbito da disciplina de Práticas: a professora Velma, responsável pela disciplina; os educadores e monitoras, que deveriam orientar os licenciandos e cuidar da organização do material; os licenciandos, responsáveis pela realização do Estágio na escola. A comunidade é a própria turma, diurno e noturno, composta pela professora, licenciandos e educadores, e monitoras.

\section{A atividade discente de confeccionar o roteiro}

No momento final do turno 1, quando a professora Velma terminava a apresentação da proposta, Marcos logo lhe indagou sobre o roteiro único (turno 2). A logística da organização do material foi usada como resposta para a questão levantada, mas não parece ter sido convincente para Marcos, que fez um pedido de apresentação de uma contraproposta.

Então, ao contrário do roteiro único, a contraproposta de Marcos traz à tona uma necessidade de mudanças, uma vez que sua ideia traria uma dinâmica completamente diferente tanto da proposta da professora quanto do que vinha sendo feito na disciplina até aquele momento. Marcos apresentou uma proposta que contemplava o rodízio de roteiros, indo em direção oposta à ideia de um roteiro único.

Com o rodízio de roteiros haveria um rodízio de experimentos que talvez demandasse a participação de forma efetiva dos licenciandos no que se refere à própria confecção dos 
roteiros bem como ao planejamento e a sua execução durante o estágio. Talvez envolvesse ainda maior colaboração entre os próprios licenciandos ou mesmo entre estes e o professor da escola, uma vez que teriam que planejar juntos sobre a aula em que haveria o rodízio de experimentos. Dessa forma, Marcos estaria apresentando a necessidade de alguns dos outros licenciandos no que se refere a participação mais efetiva na elaboração dos roteiros e no próprio processo de se tornar professor, pois estaria contribuindo com uma participação maior também dos alunos.

Para corroborar com a nossa interpretação sobre a necessidade dos licenciandos de efetiva participação, apresentamos o trabalho do Rodrigues (2013), o qual investigou a mesma disciplina aqui analisada. Ao abordar a questão do roteiro, o autor faz um relato de como este foi se constituindo no âmago da disciplina de Práticas em Ensino de Física, descrevendo como era feito nos anos anteriores até aquele momento. Ele apresenta alguns episódios que revelam que alguns licenciandos em 2010 já estavam modificando os roteiros para ajustá-los à realidade das turmas nas quais estagiavam na Escola. Alguns desses episódios ocorreram antes mesmo da proposta de confeccionar o roteiro.

Da mesma forma, em nosso trabalho de doutoramento (SILVA, 2013) é possível encontrar com mais detalhes as transcrições das falas de algumas duplas de estagiários durante as oficinas, indicando a demanda dos licenciandos por mudar efetivamente os roteiros. Lembramos que as oficinas eram destinadas para preparação e planejamento do que seria feito na Escola.

Portanto, na Figura 3 se encontra a representação da atividade dos licenciandos, tendo o rodízio do roteiro como objeto, configurando-se assim em outra atividade.

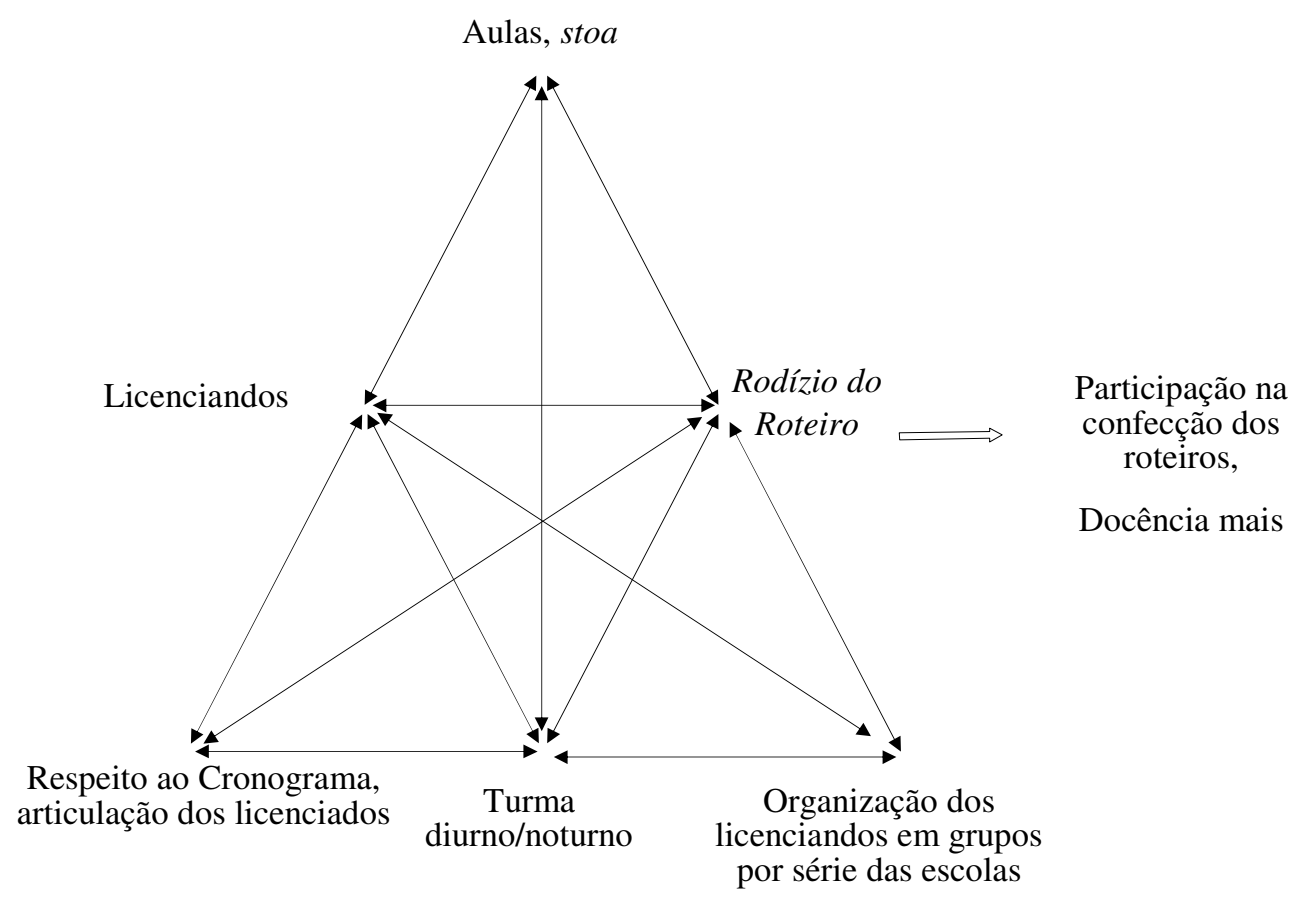

Figura 3: Atividade dos licenciandos, como contraproposta à atividade proposta pela professora. 
Da mesma forma que a atividade docente, o rodízio do roteiro, tal como proposto por Marcos, representa uma idealização do objeto, "cuja real função é orientar o sujeito no mundo objetivo" (LEONTIEV, 2009, p.2). Contudo, há uma condição importante para que os dois momentos ocorram, que é apontado por Leontiev (2009) como encontro entre a necessidade do sujeito e o objeto: "o encontro da necessidade com o objeto é um extraordinário ato" (p 88).

O rodízio do roteiro, enquanto objeto, "já está contido implicitamente na atividade" (LEONTIEV, 2009), isto é, na atividade de estágio dos licenciandos, uma vez que eles já conheciam a realidade da escola. Por outro lado, eles já conheciam bem a rotina de preparação dos experimentos cujos roteiros já vinham prontos. Assim, estamos dizendo que o rodízio do roteiro surge na forma de imagem para os licenciandos, mas também "como em forma de tarefas, problemas e ações discretas" (ENGESTRÖM, 1987, p 78).

Em outras palavras, a proposta de rodízio de roteiros surge da experiência de estágio dos licenciandos, tanto nas oficinas quanto na própria escola, tal que imaginar/propor o rodízio de roteiros não seria uma ideia completamente fora do escopo da disciplina, mas ao mesmo tempo, seria completamente diferente do que era realizado na disciplina de Práticas até aquele momento, pois implicaria numa possibilidade de participação maior dos alunos.

\section{A atividade discente-docente de personalizar o roteiro}

$\mathrm{Na}$ aula do dia 30/08/2010, quando a professora anunciou o cancelamento da elaboração dos roteiros do terceiro bloco, ela precisou replanejar a aula. Ao mesmo tempo, talvez devido ao clima de frustração, a professora demonstrou sua preocupação com o andamento da disciplina, ao dizer "estou com uma sensação de que as coisas não estão indo muito bem" (professora Velma, turno 66). Então, nesse mesmo turno, ela explicita o que achava que não estava indo bem: as coisas estavam dando errado na escola, os experimentos nem sempre iam bem; os alunos da escola escreviam e ninguém entendia nada. O quadro que ela descreve é o estopim para uma rodada de avaliações e relatos dos licenciandos sobre os trabalhos de estágio. O movimento de avaliação dos licenciandos proporciona uma visão geral e concreta do que acontecia na escola. Foi no embalo desse movimento que surge a ideia de personalizar o roteiro.

Os acontecimentos nos turnos 67 a 70 dão as condições iniciais para a nova atividade, na medida em que os estagiários relatam que tiveram o experimento trocado. A discussão passa, então, para os tipos de experimentos a serem usados nas diversas situações de ensinoaprendizagem. Na sequência, no turno 80 o Educador comenta a experiência, aparentemente bem sucedida, de Digão que preparava o seu próprio roteiro tomando como referência o tema do experimento para dada aula a fim de adaptá-lo à turma em que estagiava. O Educador 
completa dizendo que outras duplas adotaram o mesmo procedimento nas oficinas subsequentes no dia, como mostra o trabalho do Rodrigues (2013).

O comentário do educador no turno 80 funcionou como a chave para a professora propor a todos os licenciandos o mesmo procedimento. No turno 81, ela fala que "talvez seja melhor investir em personalizar os roteiros" (professora Velma), adequando-os às turmas. Assim, personalizar os roteiros surge como uma nova proposta de atividade para ser desenvolvida pelos licenciandos.

A Figura 4, a exemplo das outras atividades, mostra a atividade discente-docente de personalizar o roteiro, ou seja, o objeto da atividade é personalizar os roteiros do terceiro bloco de atividades. É importante notar que personalizar é também confeccionar, porém, numa conjuntura completamente diferente, pois não parte apenas da equipe pedagógica. A nova atividade emerge do processo da combinação de fatores, entre estes a realidade da escola, que levou a atividade docente ao fracasso. Assim, a atividade de personalizar não é nem apenas docente nem discente, mas é da relação discente-docente.

Aulas, oficinas, situações concretas do estágio

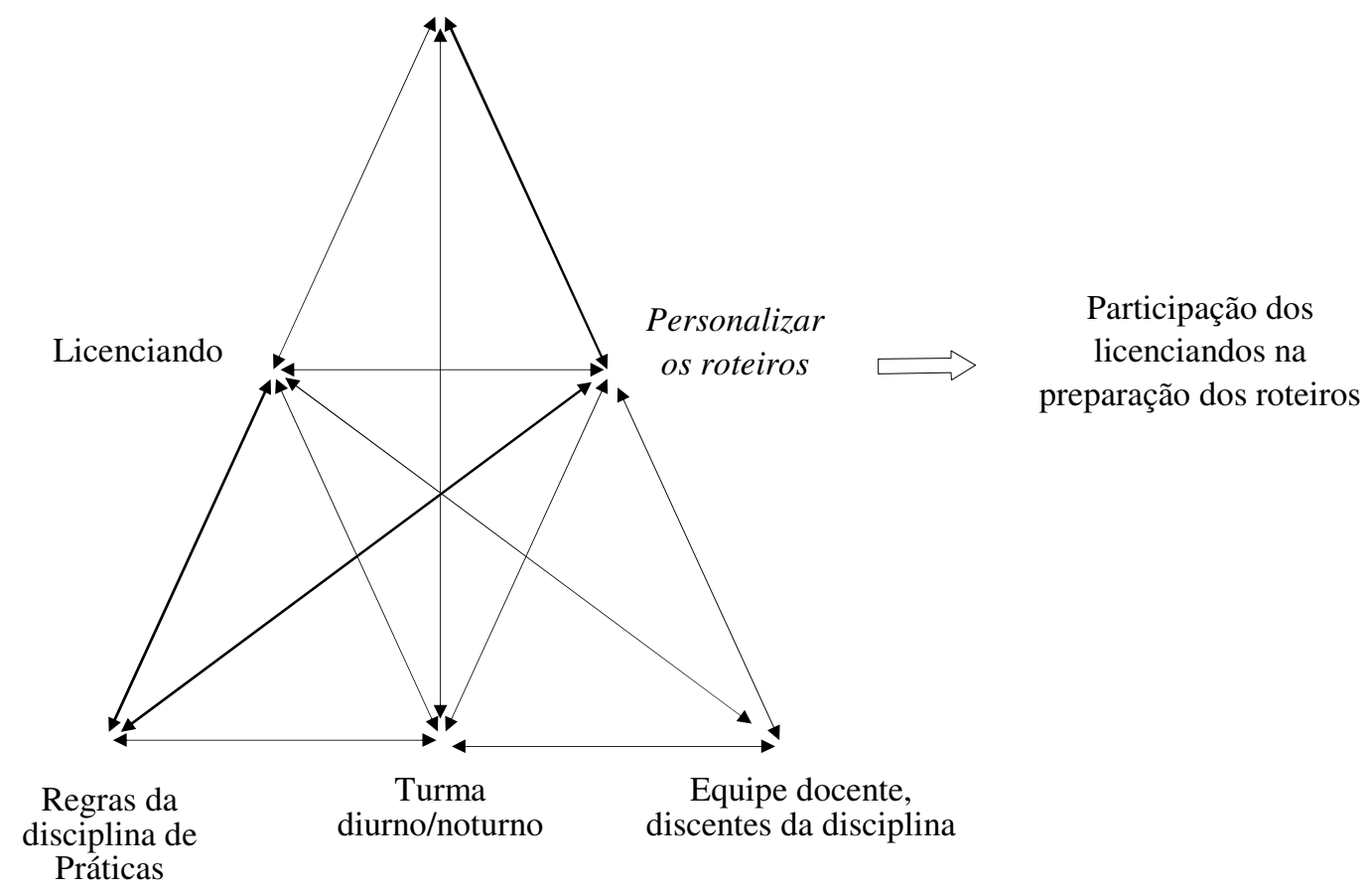

Figura 4: Modelo da atividade discente-docente de personalizar os roteiros.

Considerando-se, então, a relação entre o desenvolvimento da atividade e o seu objeto, podemos dizer, em suma, que a atividade se desenvolve em dois momentos principais. Primeiro, a mudança das condições do objeto, de existência independente para uma imagem subjetiva; segundo, a transformação dessa imagem subjetiva em resultado, em produto. $\mathrm{O}$ 
primeiro processo está associado à apropriação do objeto pelo sujeito e o segundo se refere ao processo de objetivação, isto é, "a transição ou 'tradução' do objeto refletivo na imagem subjetiva" (LEONTIEV, 2009, p.3) em produto, em resultado da atividade.

Assim, o processo de transformação do objeto da atividade docente e discente proporcionou o surgimento de um novo objeto de uma nova atividade, discente-docente. $\mathrm{O}$ roteiro, enquanto objeto das atividades, passa por transformações nas diferentes atividades, de tal forma que personalizar o roteiro configura-se como uma "objetivação da necessidade, 'enchendo-a' com o conteúdo derivado do mundo ao redor" (LEONTIEV, 2009, p. 88) na medida em que representa uma síntese de confeccioná-lo e promover o rodízio. É importante ressaltar que "a principal coisa que distingue uma atividade de outra é a diferença de seus objetos" (DANIELS, 2003, p. 115).

\section{Contradição entre a iniciativa e a limitação}

Considerando a apresentação da proposta da professora Velma de confeccionar os roteiros dos experimentos, parece-nos, então, que aos licenciandos já lhes tinham sido prescritas as suas ações da atividade de confeccionar os roteiros, sobrando apenas espaço para eles nas suas operações. Logo, as ações (prescritas) dos licenciandos são ao mesmo tempo as regras da atividade de confeccionar o roteiro. Uma vez que tais ações não são dos próprios sujeitos, podemos dizer que há uma contradição entre os sujeitos e as regras expressa em termos da tensão entre a iniciativa e a limitação.

Em nosso caso específico, essa contradição ganha materialidade ao se definir a ideia do roteiro único para os licenciandos elaborarem. Logo, se aquelas ações prescritas pela professora já caracterizam bem a contradição iniciativa-limitação, é com o estabelecimento do roteiro único que a tensão se intensifica, reduzindo o horizonte de possibilidades de ações dos licenciandos. Embora o roteiro único seja a principal regra da atividade que mais limita, podemos apresentar outras que mantém essa mesma característica, por exemplo, a escolha dos experimentos deveria estar de acordo com os temas já definidos pelos professores das escolas no início do ano.

De acordo com Engeström e Sanino (2011), as contradições são manifestas de diferentes formas no discurso dos sujeitos, como por exemplo, a fala de Marcos no turno 2 ou um trecho da fala da professora ainda no turno 1. Marcos parece ser bem enfático ao questionar a professora sobre o roteiro único. Ora, ele não fez outra coisa a não ser tornar explícito que a proposta do roteiro único não trazia grandes novidades do que já estava sendo feito na disciplina até aquele momento. Os eventos tornam evidente sua denúncia com relação a não mudança efetiva, isto é, roteiro único era o que vinha sendo feito até então. 


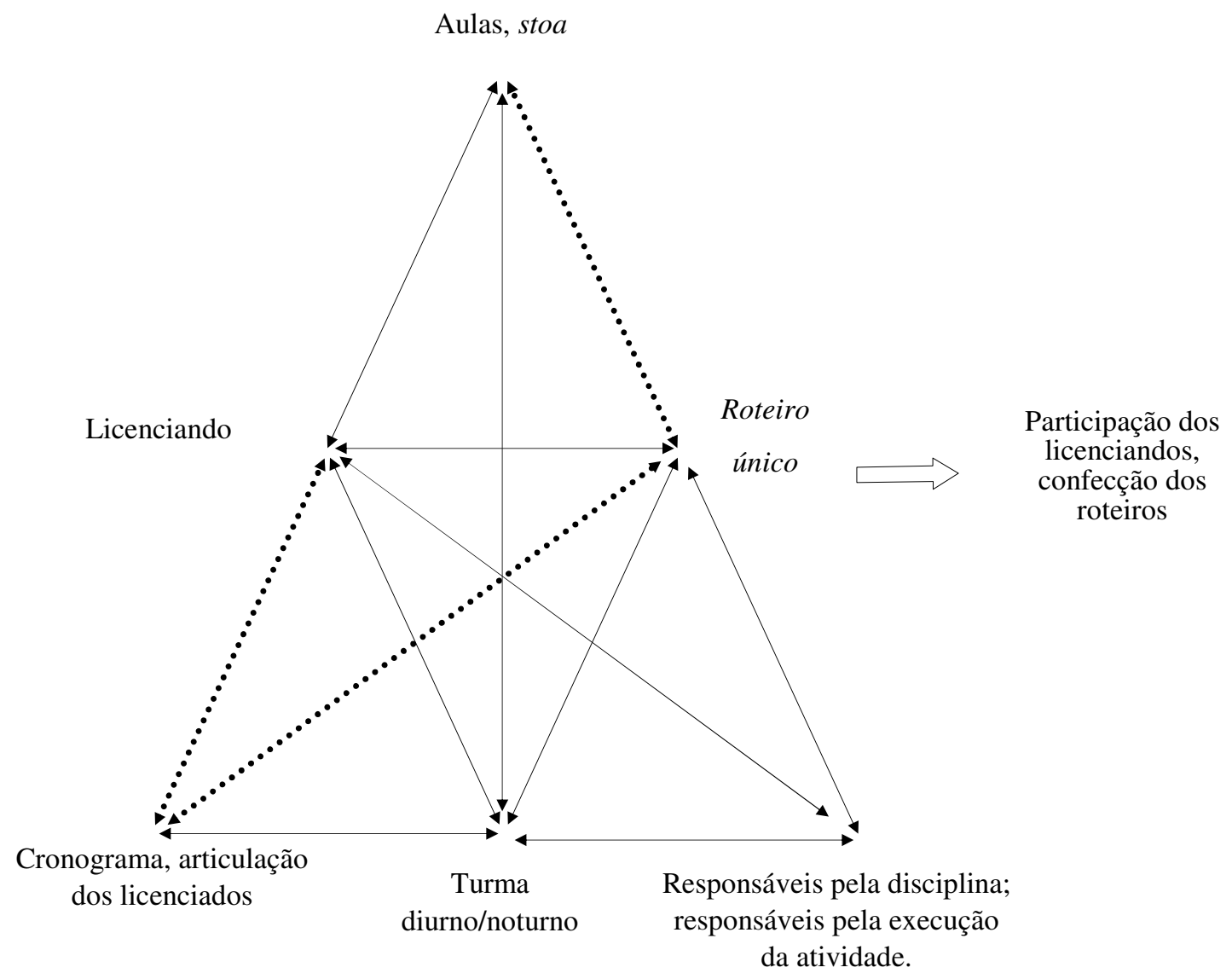

Figura 5: Representação da contradição secundária, entre o sujeito agente e a regra e entre a regra e o objeto, e entre este e o instrumento na atividade proposta de confeccionar o roteiro.

Na figura 5 representamos por meio das setas pontilhadas as contradições que ocorrem entre os elementos da atividade. Por outro lado, o desenvolvimento da atividade de confeccionar o roteiro, em seu momento inicial, ocorre com o desmembramento, por assim dizer, entre a atividade docente e a atividade dos licenciandos. Trata-se dos diferentes sentidos que a professora e a equipe pedagógica e os licenciandos atribuem para a atividade de confeccionar o roteiro.

\section{A noção do objeto compartilhado}

O objeto é o que move o sujeito no decurso da atividade, uma vez que é nesta que ocorre, segundo Leontiev (2009), a transformação do objeto idealizado em material. Assim, o objeto orienta a atividade do sujeito, a qual vai se desenvolver nas suas ações e nas operações.

Engeström (2001) apresenta a evolução da Teoria da Atividade em três diferentes gerações: a primeira estaria em torno das ideias de Vigotski sobre a mediação cultural das ações entre sujeito e objeto; a segunda geração seria aquela representada pelo triângulo em que Engeström (1987) propõe a expansão das tríades de mediação (Figura 1); na terceira, torna-se explícito um aspecto primordial que não estava sendo considerado nas outras duas 
que é a noção da diversidade. Engeström (2001) explica que "precisava desenvolver instrumentos conceituais para entender o diálogo, perspectivas múltiplas e networks de interação entre sistemas de atividade" (p. 135), apontando o compartilhamento entre os objetos, conforme indica a Figura 6.

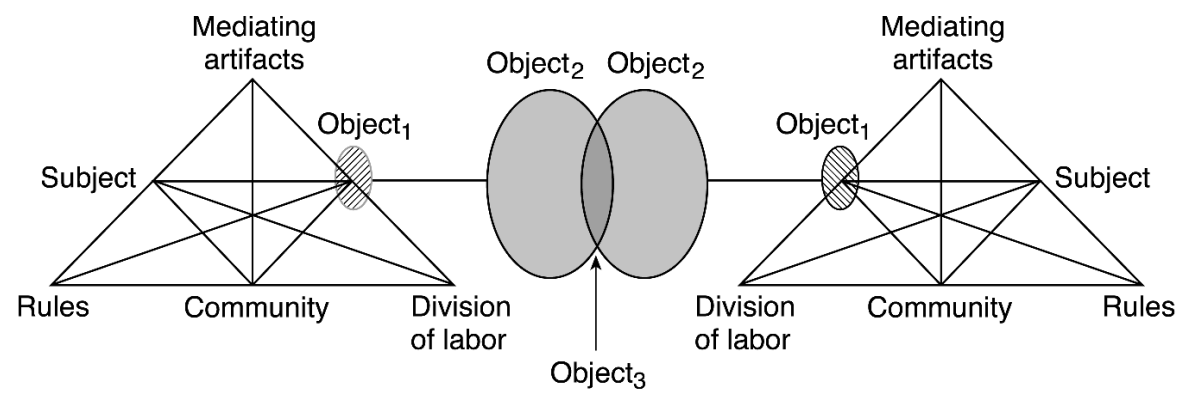

Figura 6: Modelo apresentado por Engeström (2001) representando a terceira geração da teoria da atividade no qual há dois sistemas de atividades interagindo.

De acordo com Engeström (2001), ocorre uma espécie de negociação entre o objeto 1 e o objeto 2, cujo resultado é um terceiro objeto, o qual não é "reduzível a objetivos conscientes imediatos" (ibid, p. 136). A terceira geração da atividade demanda o desenvolvimento dos instrumentos conceituais comuns para que se estabeleça o diálogo, e então, se compreenda as diferentes perspectivas e diferentes redes de interação do sistema de atividade.

Na Figura 7 buscamos representar o compartilhamento do objeto entre as atividades da professora e as dos licenciandos. Trata-se de um processo de transição e transformação do objeto, representando processo da atividade discente-docente de personalizar os roteiros cujos objetos são compartilhados.

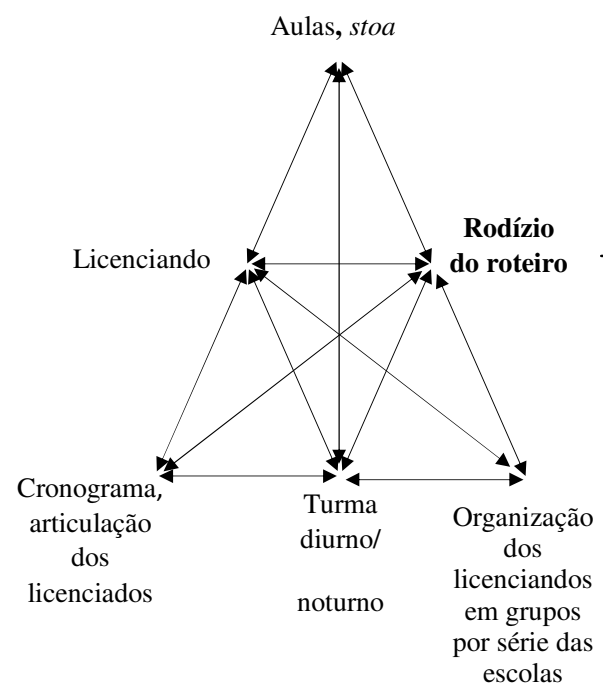

Aulas, cronograma,

instrumentos pedagógicos

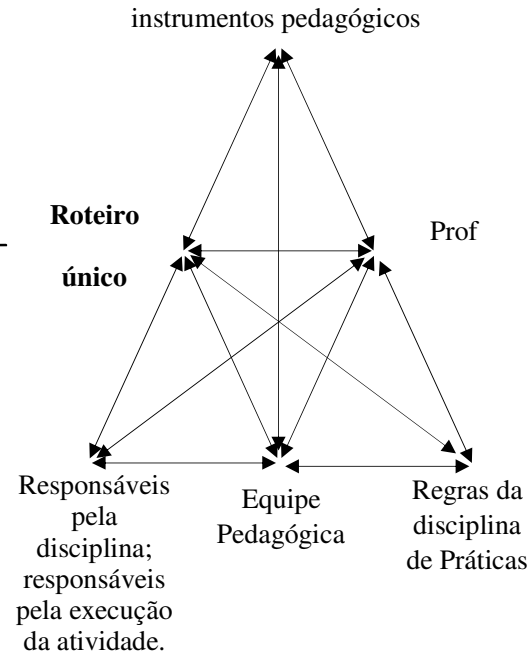

Figura 7: O compartilhamento de um novo objeto entre os licenciandos e a professora. 
A atividade de confeccionar os roteiros foi elaborada na reunião de trabalho pela equipe pedagógica (atividade docente), na qual não tinha nenhum representante dos licenciandos. A nova proposta emerge no decurso da aula, isto é, seu surgimento ocorre no interior de outra comunidade, que não é a da equipe pedagógica (atividade docente) nem a dos licenciandos (atividade discente).

A Figura 7 representa essa constituição do terceiro objeto a partir dos objetos das atividades discente (esquerda) e atividade docente (direita). Trata-se, portanto, de um novo objeto e uma atividade, na qual os sujeitos são os licenciandos e a professora. O novo objeto da atividade são os roteiros personalizados, cujas regras parecem mais flexíveis, estabelecidas pela professora no turno 81. Assim, a adequação dos roteiros às turmas em que os licenciandos cumpriam o estágio fica sendo a regra dessa nova atividade, sob a justificativa de que os licenciandos já conhecem as turmas e estão familiarizados com os alunos e com o professor supervisor. Os instrumentos passam a ser as oficinas, o stoa e outros elementos da disciplina de Práticas.

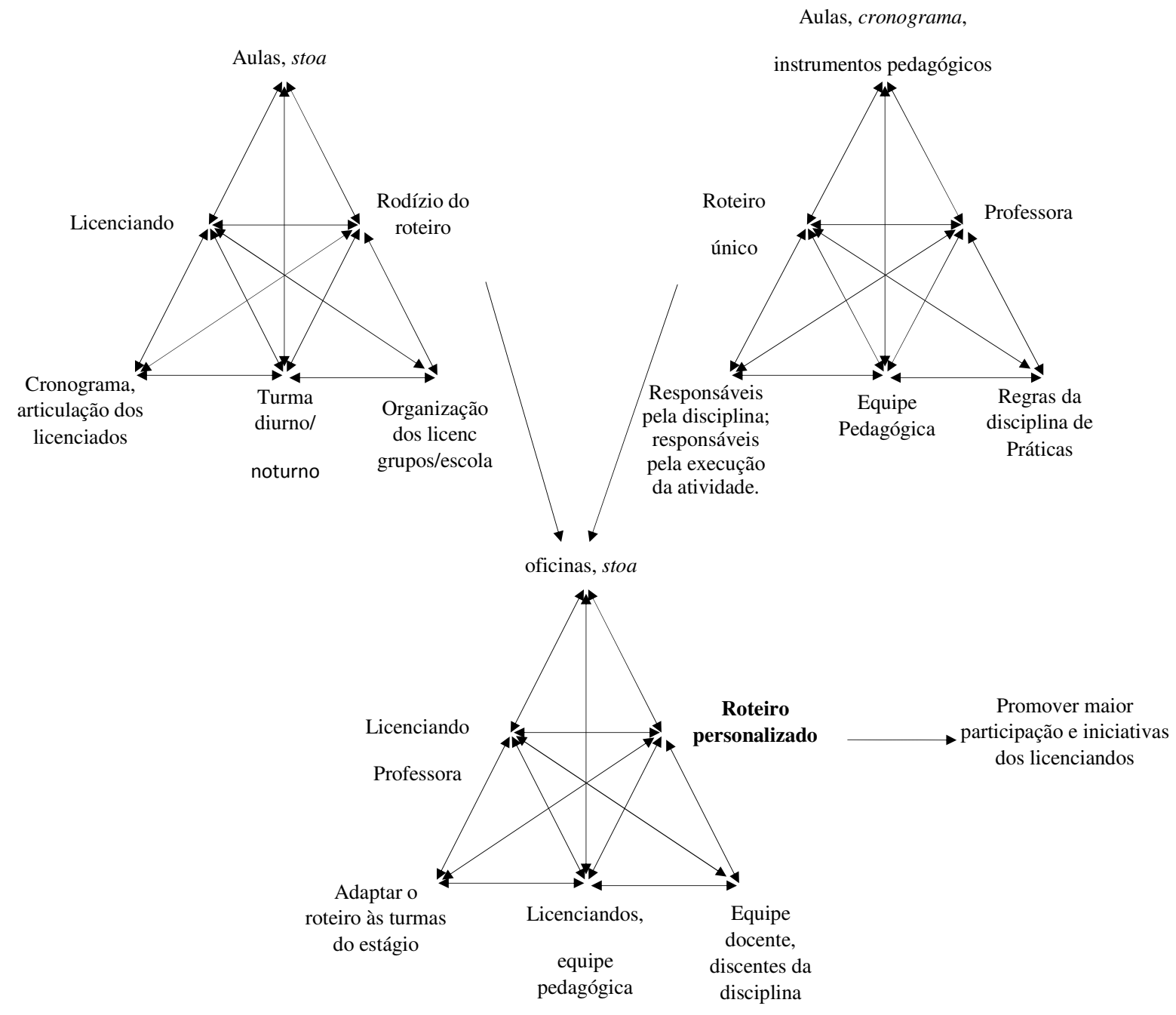

Figura 8: Representação do novo objeto e da nova atividade discente-docente, destaque para a nova comunidade no triângulo na parte inferior da figura. 
Daniels (2003) discute as gerações da Teoria da Atividade em um capítulo inteiro dedicado às Teorias Socioculturais. A perspectiva dos sistemas de atividades tem como fundamento básico a noção de que a "a unidade de análise para a teoria da atividade é a atividade ou prática conjunta, não a atividade individual" (p.120). O interesse é o "processo de transformação social (...), levando em conta a natureza conflituosa da prática social [cuja] instabilidade (tensões internas) e a contradição" (ibid) são forças de transformação e desenvolvimento da atividade. Daniels (2003) conclui que "as transições e reorganizações nos sistemas de atividade e entre eles" modificam não apenas o sujeito, mas o próprio ambiente também é modificado (ibid). Portanto, a contradição entre a iniciativa e a limitação funciona como essa força transformadora na atividade de confeccionar o roteiro, fazendo surgir uma nova atividade de personalizar o roteiro.

\section{Considerações finais}

Neste trabalho foi analisado o que estamos chamando de atividade de confeccionar os roteiros de experimentos no contexto da disciplina de Práticas em Ensino de Física, conforme já apresentado anteriormente. A ênfase da análise está no processo de transformação da atividade na medida em que o objeto se modifica (do roteiro único ao roteiro personalizado). A atividade docente de confeccionar os roteiros tinha esquema de organização e divisão do trabalho próprios e foi confrontada pela atividade discente, a qual apresentava uma perspectiva de maior participação dos licenciandos na elaboração dos roteiros. A contradição limitação-criatividade proporcionou a nova atividade discente-docente de personalizar os roteiros. A análise desse processo revela aspectos importantes da relação entre os licenciandos, professores e a própria disciplina, os quais nos proporcionam um melhor entendimento de algumas perspectivas da relação entre a universidade e a escola, no contexto do Estágio Supervisionado.

A proposta de personalizar o roteiro ao mesmo tempo em que valida uma prática emergente na disciplina, apresenta-se como um convite para que se torne uma prática comum entre discentes e a professora. Por outro lado, ela parece ter vindo como forma de superação de algumas das contradições da atividade de confeccionar o roteiro, como já apontamos na seção anterior. Assim, é possível concluir que a superação da contradição da atividade de confeccionar o roteiro é o surgimento da atividade de personalizar o roteiro. Enquanto que primeira era uma atividade docente, a segunda é uma atividade discente-docente (Figura 8) que emerge da situação concreta da professora Velma, por um lado, e por outro, dos problemas concretos dos licenciandos vivenciados no Estágio.

$\mathrm{O}$ aspecto mais importante para ser destacado na representação da Figura 8 é a relação entre a transformação do objeto e da atividade com o processo de aprender/se tornar professor 
de Física. Em nosso trabalho anterior (SILVA; VILLANI, 2012), analisamos a disciplina de Práticas enquanto um sistema de atividades e mostramos que as transformações do objeto proporcionaram momentos distintos na disciplina relacionados com o processo de se tornar professor. O primeiro, momento estudante, o objeto da atividade dos licenciandos era a Física, ou seja, a atividade estava orientada para os licenciandos aprenderem Física. O seguinte, momento estagiário, de caráter intermediário, a atenção dos licenciandos se volta para a escola e os problemas que surgiram no início do estágio. Por fim, o momento professor, o objeto dos licenciandos passa ser ensinar Física. Esses três momentos estão cronologicamente sequenciados. Destacamos na presente análise que a transformação da atividade de confeccionar o roteiro em atividade de personalizar o roteiro está inserida no terceiro momento, uma vez que os licenciandos demandam a participação no processo de elaboração dos roteiros.

Portanto, a análise do processo do surgimento de uma nova atividade no contexto da disciplina de Práticas revela um aspecto importante da formação inicial de professores na medida em que indica os momentos em que o licenciando se atenta mais para o como ensinar Física do que aprendê-la. Em termos teóricos, dizemos que "um objeto é ao mesmo tempo algo dado e algo projetado ou antecipado. Uma entidade no mundo externo se torna um objeto da atividade quando encontra a necessidade humana" (ENGESTRÖM, 2008, p. 89). Consequentemente, o elemento central nesse processo é a experiência do estágio, isto é, uma situação concreta de ensino, como provocadora de mudanças na atividade proposta pela professora Velma. O roteiro personalizado significa para os licenciandos ensinar Física que é objeto do terceiro momento.

Por outro lado, a análise com base na Teoria da Atividade nos permite pensar de uma forma mais ampla o problema abordado neste artigo, se considerarmos a Universidade e a Escola como sistemas de atividade distintos, mas que têm algum tipo de relação entre si, isto é, ambas as instituições têm relação com a formação de professores. Se para universidade formar professores é parte integrante de sua atividade, para escola, esta não parece ser uma ação de sua atividade, muito embora a prática do Estágio Supervisionado se desenvolva no âmbito da escola. A perspectiva aplicacionista não fez da escola um locus de formação inicial de professores, consequentemente, a prática do estágio não se constitui em uma ação da escola, mas sempre da universidade na escola. Logo, esse movimento da universidade de ir para escola, parece não se constituir em uma parceria, senão uma simples presença, nem sempre bem quista por alguns professores e gestores.

Contudo, os documentos legais sobre a formação docente, há uma década vem apontando para outra direção ao prever a escola como coformadora, instituindo, dessa forma, uma nova ação para a sua atividade, a de formar professores. Em outras palavras, formar 
professores também seria uma ação da atividade da escola, mesmo que os seus modos de execução sejam distintos dos modos execução da atividade da universidade. De acordo com Leontiev (1986), "o propósito de um mesmo ato pode ser percebido diferentemente, dependendo de qual é o motivo que surge precisamente em conexão com ele" (p.72). Então, defendemos que a perspectiva coformadora de professores, quer seja a inicial, quer seja continuada deverá se constituir a partir de uma relação de colaboração entre as duas instituições em questão, a Universidade e a Escola. Nesse sentido, o estabelecimento de uma colaboração deverá ocorrer a partir do surgimento do objeto comum (Figura 6) para a atividade de formar professores. Em outras palavras, estamos dizendo que é necessária uma atividade universidade-escola de formar professores, como representado na Figura 8. A perspectiva colaborativa, então, coloca-nos na interface dos Sistemas de Atividades, ou de acordo com Jahreie e Ottesen (2010) e Tsui e Law (2007), na região de fronteira entre os Sistemas.

Jahreie e Ottesen (2010), usando a Teoria da Atividade, apresentam a ideia de fronteira ao abordar a formação inicial de professores a partir da relação entre o Departamento de Educação da Universidade e as Escolas parceiras, nas quais se desenvolve o que seria o Estágio Supervisionado. Os autores afirmam que "quando a construção do objeto é investigada ao longo do tempo e através de [sistemas] de atividades, fronteira é o conceito chave (...). As fronteiras são intrínsecas nos sistemas de atividades, mas se tornam transparentes nas ações dos participantes" (p. 216). Considerando essa perspectiva de Jahreie e Ottesen (2010), o processo de transformação da atividade é marcado pela trajetória dos licenciandos na e pelas fronteiras entre dois sistemas de atividade, a Universidade e a Escola, ou seja, o Estágio Supervisionado pode ser entendido como fronteira entre as atividades se compreendido como uma atividade universidade-escola.

Na mesma direção, Tsui e Law (2007) apresentam um estudo sobre a parceria universidade e escola usando a Teria da Atividade como referencial teórico. As autoras também analisam uma situação semelhante ao Estágio Supervisionado e discutem o processo de aprendizado no que elas definiram como uma zona de fronteira. Elas afirmam que "as fronteiras geralmente são vistas como fontes de dificuldades potenciais. Contudo, elas [as fronteiras] também proporcionam oportunidades para inovação e renovação. $\mathrm{O}$ cruzamento de fronteiras força os participantes a terem um novo olhar para suas práticas e concepções (...)" (p. 1290). Assim, é possível entender a contradição entre a iniciativa e a limitação que emerge da experiência dos licenciandos de cruzar as fronteiras da disciplina de Práticas (Universidade) e da Escola. Experiência esta não vivenciada pela professora e equipe pedagógica. 
Nesse sentido, retomando a defesa de Pimenta e Lima (2005/06) de atribuir um estatuto epistemológico para o Estágio, as duas pesquisas acima relatadas sugerem a ideia de conceber o Estágio Supervisionado como uma região de fronteira. Isto é, pelo menos, entre a Universidade e a Escola, já que não estamos discutindo o papel das Secretarias Municipais e Estaduais, cuja colaboração pode ser uma das ações da atividade universidade-escola (Figura $8)$.

Os diferentes referenciais teóricos e metodológicos possibilitaram o desenvolvimento de diferentes modelos de formação de professores. Um dos modelos mais marcantes e que ainda persiste em alguns cursos de licenciatura é aquele que ficou conhecido como racionalidade técnica que se apoia na concepção de que a "prática educacional é baseada na aplicação do conhecimento científico, e questões educacionais são tratadas como problemas 'técnicos', os quais podem ser resolvidos objetivamente por meio de procedimentos racionais da ciência" (DINIZ-PEREIRA, 2007, p.254). Outros dois modelos são destacados, baseados na racionalidade prática e racionalidade crítica. Assim, se considerarmos as legislações (BRASIL, 2015) e algumas políticas públicas recentes (como o Pibid $^{7}$ ), é possível perceber uma crescente demanda para os modelos de formação de professores baseados na colaboração, tal que podemos nos arriscar a dizer que estaríamos caminhando para um tipo de racionalidade colaborativa enquanto modelo de formação docente, cuja constituição de compartilhamentos de objetos na fronteira de um Sistema de Atividades seria sua característica principal.

Como conclusão, o caso aqui analisado nos coloca diante da centralidade da escola no processo de formação inicial de professores, especificamente, no Estágio Supervisionado, pois é quando os licenciandos devem estar diretamente na escola. Contudo, a relação entre universidade e escola é marcada por um tipo de contradição semelhante à analisada neste artigo, uma vez que o "cruzamento de fronteiras proporciona a inovação" (TSUI; LAW, 2007, p. 1290). A noção de iniciativa e limitação aparece, por exemplo, nos enlaces institucionais. Por um lado, o estágio supervisionado é uma disciplina da universidade, isto é, tem uma quantidade de créditos, uma nota a ser dada, carga horária do orientador, etc. Podemos dizer que funciona então, como uma limitação, pois restringe a ação dos estagiários. Mas por outro lado, o estágio se instala na própria escola cuja dinâmica de sala de aula e relação professoraluno são características marcantes, funcionando, assim, como iniciativas por parte do estagiário ou do supervisor que vivenciam a experiência da sala de aula. A tensão limitaçãoiniciativa entre a universidade e escola encontra uma possibilidade de solução na medida em

\footnotetext{
${ }^{7}$ O Programa Institucional de Bolsas de Iniciação à Docência (Pibid) apresenta entre os seus objetivos a coformação de professores e considera a Escola de Educação Básica como coformadora. Essa concepção reforça a parceria entre Universidade e Escola, não apenas a segunda como local da aplicação de teorias da primeira.
} 
que se encontra um objeto em comum e, portanto, a mesma atividade. Entendemos que esse processo passa pela instalação da racionalidade colaborativa

\section{Referências}

BRASIL. Diretrizes Curriculares Nacionais para a Formação de Professores da Educação Básica, em nível superior, curso de licenciatura, de graduação plena. Brasília-DF: Ministério da Educação, 2001. Disponível em: <http://portal.mec.gov.br/cne/arquivos/pdf/009.pdf> Acesso em: 17/11/2016.

BRASIL. Diretrizes Curriculares Nacionais para a Formação Inicial e Continuada dos Profissionais do Magistério da Educação Básica. Brasília-DF: Ministério da Educação, 2015. Disponível em:

<http://pronacampo.mec.gov.br/images/pdf/parecer_cne_cp_2_2015_aprovado_9_junho_201 5.pdf> Acesso em: 17/11/2016.

BRASIL. Instrumento de Avaliação de Cursos de Graduação Presencial e a Distância. Brasília-DF: Ministério da Educação, 2016. Disponível em:

$<$ http://download.inep.gov.br/educacao_superior/avaliacao_cursos_graduacao/instrumentos/2 016/instrumento_2016.pdf> Acesso em: 17/11/2016.

DANIELS, H. Vygostky e a Pedagogia. São Paulo: Edições Loyola, 2003.

DINIZ-PEREIRA, J. E. Paradigmas contemporâneos da formação docente. In: SOUZA, J. V. A. (Org). A formação de professores para a Educação Básica: dez anos da LDB. Belo Horizonte: Autêntica, 2007. p. 253-264

CALDERANO, M. A. Docência compartilhada entre universidade e escola: formação no estágio curricular. São Paulo: FCC/SEP, 2014.

CAMILLO, J.; MATTOS, C. Educação em Ciências e a Teoria da Atividade CulturalHistórica: contribuições para a reflexão sobre tensões na prática educativa. Revista Ensaio, v. 16, n. 01, p. 211-230, 2014.

CARVALHO, A. M. P. Uma metodologia de pesquisa para estudar os processos de ensino e aprendizagem em salas de aula. In: SANTOS, F. M. T.; GRECA, I (orgs). A pesquisa em ensino de ciências no Brasil e suas metodologias. Ijuí-RS: Unijuí, 2006. p. 13-48.

ENGESTRÖN, Y. Learning by expanding: an activity-theoretical approach to developmental research. Helsinki: Orienta-Konsultit, 1987.

ENGESTRÖN, Y. Expansive learning at work: Toward an activity theoretical reconceptualization. Journal of Education and Work, v. 14, n. 1, p.133-154, 2001.

ENGESTRÖN, Y. From teams to knots: Activity-Theoretical Studies of collaboration and learning work. New York: Cambridge University Press, 2008.

ENGESTRÖM, Y.; SANINO, E. Discursive manifestations of contradictions in organizational change efforts: A methodological framework. Journal of Organizational Change Management, v. 24, n. 3, p. 368-387, 2011.

ERICKSON, F. Qualitative research Methods for Science Education. In: FRASER, J. B.; TOBIN, K. G.; CAMPBELL, J. M (Ed). Second International Handbook of Science 
Education. Part two. Dordrechit, Heidelberg, London, New York: Springer. 2012. p. 14511469

GATTI, B. A. Formação inicial de professores para educação básica: pesquisas e políticas educacionais. Est. Aval. Educ. São Paulo, v. 25, n. 57, p. 24-54, 2014.

GOULART, S. M. A prática de ensino na formação de professores: uma questão (des) conhecida. Revista da Universidade Rural, Série Ciências Humanas. UFFRJ, v. 24, n 1-2, p. 77-87, 2002.

JAHREIE, C. F.; OTTESEN, E. Construction of boundaries in Teacher Education: analyzing student teachers' accounts. Mind, Culture and Activity, v. 17, n. 3, p. 212-234, 2010.

LEONTIEV, A. N. O desenvolvimento do Psiquismo. Lisboa: Livros Horizonte, 1978.

LEONTIEV, A. N. A. Uma contribuição à teoria do desenvolvimento da psique infantil. In: VIGOSTIKI, L. S.; LURIA, A. R.; LEONTIEV, A. N. Linguagem, desenvolvimento e aprendizagem. São Paulo: Ícone Editora, 1986. p. 59-83.

LEONTIEV, A. N. A. Activity and consciousness. Pacifica, USA: Marxists Internet Archive, 2009. Disponível em: <https://www.marxists.org/archive/leontev/works/activityconsciousness.pdf>. Acesso em 17/11/2016.

LÜDKE, M. Universidade, escola de educação básica e o problema do estágio na formação de professores. Revista Brasileira de Pesquisa sobre Formação Docente, v. 1, n. 1, p. 95-108, 2009.

LÜDKE, M. O lugar do Estágio na formação de professores. Educação em Perspectiva, v.4, n.1, p. 111-133, 2013.

LÜDKE, M.; ANDRÉ, M. E. D. A. Pesquisa em educação: abordagens qualitativas. Temas básicos da educação e ensino. São Paulo-SP: EPU, 1986.

NUSSBAUMER, D. An overview of Cultural Historical Activity Theory (CHAT) use in classroom research 2000 to 2009. Educational Review, v. 64, n. 1, p. 37-55, 2011.

PIMENTA, S. G; LIMA, M. S. L. Estágio e docência: diferentes concepções. Revista Poíesis,v. 3, n. 3-4, p. 5-24, 2005/06.

RODRIGUES, A. M. Movimento e Contradição: a disciplina de Práticas em Ensino de Física e a formação inicial de professores de Física sob uma perspectiva histórico-cultural. 278f.

Tese (Doutorado em Ensino de Ciências-modalidade Física). Instituto de Física/Faculdade de Educação-Universidade de São Paulo, 2013.

ROTH, W.-M. Activity Theory and Education: an introduction. Mind, Culture, and Activity, v.11, n.1, p. 1-8, 2004.

ROTH, W-M.; LEE, Y-J. Vygotsky's neglected legacy: Cultural-Historical Activity Theory. Review of Educational Research, v.77, n.2, p. 186-232, 2007.

SALEM, S. Perfil, evolução e perspectivas da pesquisa em Ensino de Física no Brasil. 385f. Tese (Doutorado em Ensino de Ciências-modalidade Física). Instituto de Física/Faculdade de Educação- Universidade de São Paulo, 2012. 
SILVA, G. S. F. A formação de professores de Física na perspectiva da Teoria da Atividade: análise de uma disciplina de práticas em ensino e suas implicações para codocência. 327f. Tese (Doutorado em Ensino de Ciências-modalidade Física). Instituto de Física/Faculdade de Educação- Universidade de São Paulo, 2013.

SILVA, G. S. F.; VILLANI, A. A formação de professores de Física no contexto de uma disciplina de Práticas em Ensino. In: ENCONTRO DE PESQUISA EM ENSINO DE FÍSICA, 14, 2012, Maresias, 2012. Disponível em:

$<$ http://www.sbf1.sbfisica.org.br/eventos/epef/xiv/sys/resumos/T0307-1.pdf > Acesso em $17 / 11 / 2016$.

STETSENKO, A. Activity as object-related: resolving the dichotomy of individual and collective planes of activity. Mind, Culture and Activity, v. 12, n. 1, p.70-88, 2005.

TSUI, A. B. M.; LAW, D. Y. K. Learning as boundary-crossing in school-university partnership. Teaching and Teacher Education, v. 23, n.8, p.1289-1301, 2007.

VILLANI, A., PACCA, J. L. A.; FREITAS, D. Science teacher education in Brazil: 19502000. Science \& Education, v.18, n.1, p.125-148, 2009.

\section{SOBRE OS AUTORES}

GLAUCO DOS SANTOS FERREIRA DA SILVA. Possui Licenciatura em Física pela Universidade Federal de Juiz de Fora (2003), mestrado (2008) e doutorado (2013) em Ensino de Ciências (Modalidade Física) pela Universidade de São Paulo, tendo realizado estágio no exterior (Programas de Bolsa Sanduíche da CAPES) junto ao Graduate Center of City University of New York (fevereiro a agosto de 2012). Atualmente é professor efetivo do CEFET/RJ - Campus Petrópolis, pesquisador no Núcleo de Atividades e Pesquisa em Ensino de Física (NAPEF) deste campus. É o atual Coordenador Institucional do Pibid e atua no Programa de Pós-graduação em Ciência, Tecnologia e Educação (PPCTE), ambos no CEFET/RJ.

ALBERTO VILLANI. Possui graduação em Filosofia - Licenza - Aloisianum Facultas Philosophica (1966), graduação em Fisica - Laurea - Universita degli Studi di Padova (1969) e doutorado em Física pela Universidade Estadual Paulista Júlio de Mesquita Filho (1972), Livre Docência pela Universidade de São Paulo(1987) e pós-doutorado pela Universitá di Bologna (1989). Atualmente é Professor Sênior no Instituto de Física e atua no Programa de Pós-graduação Interunidades em Ensino de Ciências da Universidade de São Paulo.

Recebido: 07 de junho de 2016.

Revisado: 18 de agosto de 2016.

Aceito: 01 de novembro de 2016. 